\title{
People’s Republic of China-Hong Kong Special Administrative Region: Selected Issues
}

This Selected Issues paper for People's Republic of China-Hong Kong Special Administrative Region was prepared by a staff team of the International Monetary Fund as background documentation for the periodic consultation with the member country. It is based on the information available at the time it was completed on January 12, 2005. The views expressed in this document are those of the staff team and do not necessarily reflect the views of the government of People's Republic of China-Hong Kong Special Administrative Region or the Executive Board of the IMF.

The policy of publication of staff reports and other documents by the IMF allows for the deletion of market-sensitive information.

To assist the IMF in evaluating the publication policy, reader comments are invited and may be sent by e-mail to publicationpolicy@imf.org.

Copies of this report are available to the public from

International Monetary Fund • Publication Services

700 19th Street, N.W. • Washington, D.C. 20431

Telephone: (202) 6237430 • Telefax: (202) 6237201

E-mail: publications@imf.org • Internet: http://www.imf.org

Price: $\$ 15.00$ a copy

\section{International Monetary Fund \\ Washington, D.C.}





\section{INTERNATIONAL MONETARY FUND}

\section{PEOPLE'S REPUBLIC OF CHINA- \\ HONG KONG SPECIAL ADMINISTRATIVE REGION}

\section{Selected Issues}

Prepared by Paul F. Gruenwald, Lamin Y.M. Leigh, Marcos Chamon, (all APD), Sean Craig (MFD), and Ida Liu Kit-ying (IMF Resident Representative Sub-Office in Hong Kong SAR)

Approved by the Asia and Pacific Department

January 12,2005

I. The Implications for Hong Kong SAR of Rising Integration with the Mainland ............ 3

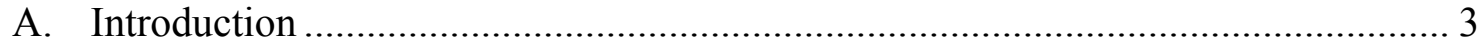

B. Economic Linkages between Hong Kong SAR and the Mainland .......................... 3

C. Integration and Business Cycles …………………............................................... 4

D. Macroeconomic Implications of Policies in the Mainland on Hong Kong SAR ..... 5

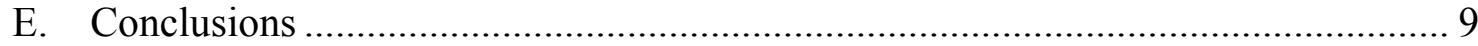

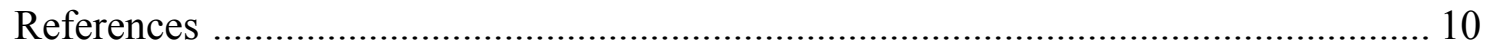

II. Hong Kong SAR's Currency Board Under Strong-side Pressures................................. 16

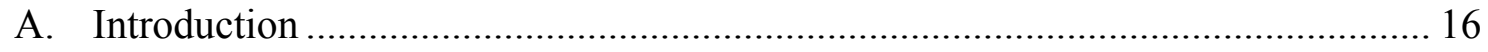

B. Hong Kong SAR's Currency Board: A Primer ...................................................... 17

C. The Initial Episode of Strong-side Pressures on the Hong Kong Dollar ............... 19

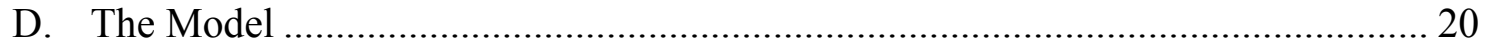

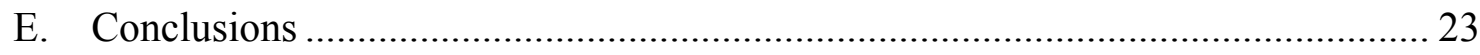

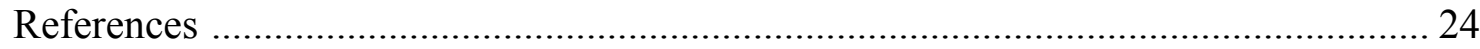

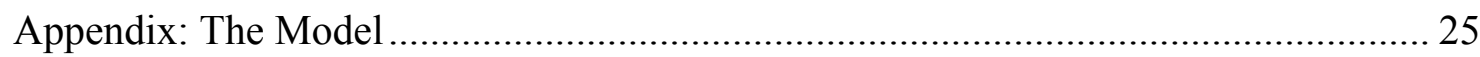

III. Procyclicality of Credit in the Banking System in Hong Kong SAR …………............ 31

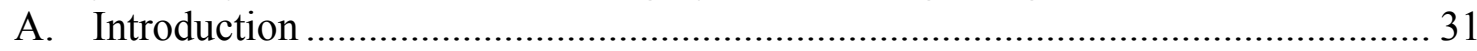

B. Features of Hong Kong SAR's Financial System Relevant to Procyclicality ....... 33

C. Extent of Procyclicality of Bank Lending in Hong Kong SAR .............................. 33

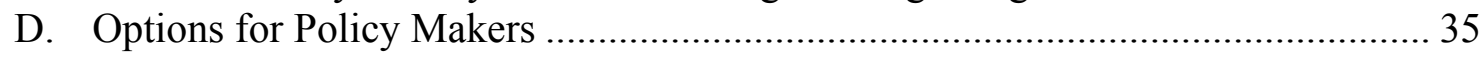

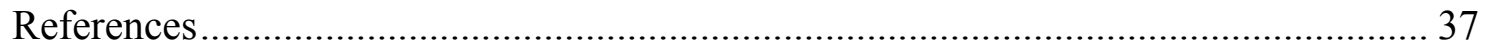

IV. Recent Labor Market Developments in Hong Kong SAR............................................ 43

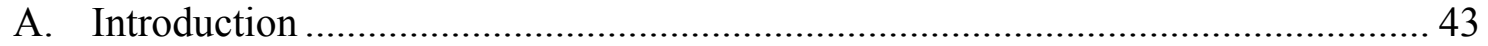

B. Rising Integration with the Mainland and Hong Kong SAR's Labor Market ....... 43

C. Measures to Address Hong Kong SAR's Labor Market Challenges ...................... 45

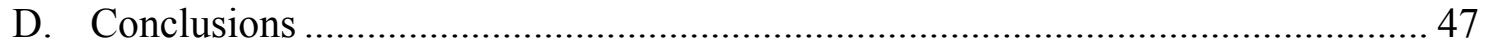

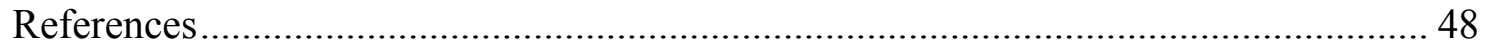


Boxes

I.1 The Closer Economic Partnership Arrangement—Free Trade Agreement between

Hong Kong SAR and Mainland China

II.1 The Evolution of Hong Kong's Currency Board Arrangements from its Inception through the Asian Crisis ..................................................................................... 27

II.2 The 1998 Strengthening of Hong Kong SAR's Currency Board Arrangements....... 28

IV.1 Hong Kong SAR Government's Report on Manpower Projections through 2007 ... 49

Tables

I.1 Hong Kong SAR: Effects of the Zero-Tariff aspect of the CEPA FTA ................... 12

III.1 Correlation Coefficients with Year-on-Year Growth in Real Credit......................... 38

III.2 Correlation Coefficients and Elasticity of Growth in Loans for Use in Hong Kong

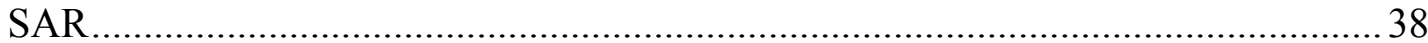

III.3 Correlation Coefficients and Elasticity of Growth in Loans with Respect to Growth in Property Prices in the Last Ten Years

Figures

I.1 Linkages between Mainland China and Hong Kong SAR and their macroeconomic effects

I.2 Hong Kong SAR and Mainland China: Degree of Concordance between the Growth

Rates of GDP and its Components...................................................................... 14

I.3 Hong Kong SAR and Mainland China: Degree of Concordance between Financial

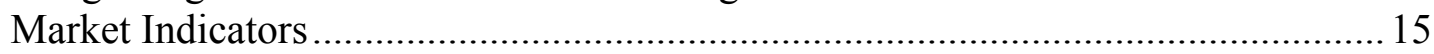

II.1 Hong Kong Dollar Spot and Forward Rates ......................................................2 29

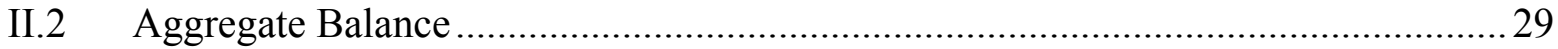

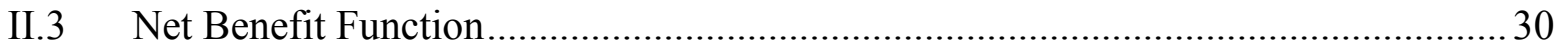

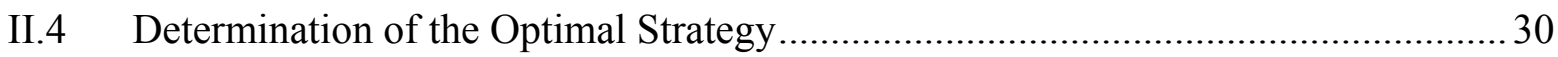

III.1 Total Loans by Type of Use (2000 Constant Prices) ........................................... 40

III.2 Real Growth of GDP and of Loans for Use in Hong Kong SAR ........................... 40

III.3 Real Growth of Loans for Use in Hong Kong SAR and of Property Prices............. 41

III.4 Real Growth of Property and Nonproperty Loans for Use in Hong Kong SAR and of Property Prices...................................................................................... 41

III.5 Ratio of Hong Kong Dollar Loans to Deposits............................................... 42

IV.1 Unemployment Rate by Occupation Category ...................................................5 50

IV.2 Unemployment Rate by Educational Attainment ................................................. 50 


\section{THE IMPLICATIONS FOR HONG KONG SAR OF RISING INTEGRATION WITH THE MAINLAND $^{1}$}

\section{A. Introduction}

1. Since 1978, Hong Kong SAR's economic integration with the Mainland has expanded rapidly. This chapter first characterizes the rapid expansion of Hong Kong SAR's economic ties with the Mainland over the last two decades. The process of integration has strengthened over the years and the two economic cycles have become increasingly synchronized. At the same time, the Mainland's own integration with the rest of the world is deepening, and these factors together have led to significant changes in the structure of Hong Kong SAR's economy.

\section{The chapter examines the possible impact on Hong Kong SAR of policy}

developments in the Mainland (including macroeconomic tightening, trade and capital account liberalization). The chapter concludes that as integration has progressed, developments in various sectors of the Hong Kong SAR economy have become increasingly tied to developments on the Mainland, which implies that macroeconomic fluctuations in the Mainland could have significant spillover effects on Hong Kong SAR. However, Hong Kong SAR also stands to benefit from the recently signed free trade agreement between the two WTO member economies as well as gradual capital account liberalization in the Mainland.

\section{B. Economic Linkages between Hong Kong SAR and the Mainland}

3. Over the last two decades, the Hong Kong SAR and Mainland economies have become increasingly linked, resulting in marked changes in the structure of Hong Kong SAR's economy.

- Hong Kong SAR's capital markets have become an important fundraising center for Mainland companies as the Mainland's capital markets are still underdeveloped. At end September 2004, Mainland issuers accounted for one-fourth of the listed companies, 30 percent of total market capitalization and 40 percent of total market turnover in Hong Kong SAR. Mainland and Hong Kong SAR banks increasingly operate in each others' territories. Direct exposure of Hong Kong SAR banks to the Mainland is small (less than 3 percent of banking sector assets) reflecting the tighter requirements on lending to Mainland companies (Figure I.1). ${ }^{2}$

\footnotetext{
${ }^{1}$ Prepared by Lamin Y.M. Leigh, ext. 36518.

${ }^{2}$ However, banks also have some indirect exposure arising from the Mainland activities of borrowers, although data to assess these activities are lacking.
} 
- The structural transformation of Hong Kong SAR's economy towards knowledge-based and high value-added activities, has led to the erosion of the demand for low-skilled workers in the labor market (see Chapter IV). As manufacturing has moved to the Mainland over the last two decades, the share of the manufacturing sector in GDP has declined from 22 percent in 1980 to less than 5 percent in 2004. Most of the manufacturing and lower-end service sectors that have migrated to the Mainland are largely labor intensive. Thus, the unemployment rate has risen faster among low-skilled workers and the wage premium commanded by high-skilled labor has increased.

- As the Mainland's access to world markets has increased, the structure of trade between Hong Kong SAR and the Mainland is changing rapidly. Thus, the share of Hong Kong SAR's entrepot trade has declined significantly, and it is increasingly getting a share of "offshore" trade that takes advantage of its superior logistical, business and financial services. ${ }^{3}$ However, the value-added of offshore trade is significantly lower than that of traditional re-export trade.

4. More recently, two Mainland-led initiatives were adopted with a view to further broaden the areas of integration.

- The Pan-Pearl River Delta (PRD) Cooperation Initiative brings together nine provinces in the region in addition to Hong Kong SAR and Macao SAR to increase economic efficiencies by better leveraging regional synergies, and to compete more effectively with the Yangtze River Delta Region. The Pan-PRD region has the potential to become a very attractive market for Hong Kong SAR's financial, logistical and other services. ${ }^{4}$

- The Closer Economic Partnership Arrangement (CEPA) which was signed in mid-2003 aims to strengthen trade and investment cooperation between Hong Kong SAR and the Mainland. It also includes a liberalization of the Mainland tourist visa scheme (that allows individual, rather than just group, visits) which has resulted in a surge in tourist arrivals from the Mainland to Hong Kong SAR (see Box I.1 for details).

\section{Integration and Business Cycles}

5. The growing integration of Hong Kong SAR and the Mainland economies has led to increasing correlation between their economic cycles. To assess the degree of synchronization of Hong Kong SAR's and the Mainland's business cycles, we use the concordance statistic originally proposed by Harding and Pagan (2002a,b) and recently

\footnotetext{
${ }^{3}$ Between 1995 and 2003, growth in re-exports of trade-related services, at 15 percent in real terms, significantly outpaced growth in re-exports involving the Mainland, which was at 7.3 percent in real terms.

${ }^{4}$ The potential offered by the Pan-PRD Cooperation initiative is enormous. The Pan-PRD region stretches from Fujian in the east to Sichuan in the west, with the Pearl River Delta in between. This area makes up one-fifth of China's land mass, contains almost a third of its population and accounts for a third of its GDP. However, the differing stages of development and income/wealth disparities will be key challenges.
} 
applied by Cashin (2004). ${ }^{5}$ These statistics show that the correlation between the two economies' output as well as the components of output (based on the concordance statistics in Figures II.2 and II.3) have increased since the mid-1990s, which suggest that integration has advanced in many sectors of the two economies. Although consumption and investment correlations have increased, they are lower than output correlations. ${ }^{6}$ Real exchange rate changes for the two economies also exhibit significantly high correlation (Figure II.3). Forward exchange rates have become highly correlated and equity market developments in the two economies have generally followed each other.

\section{The structural transformation of Hong Kong SAR's economy to a} predominantly service-based economy has been associated with a reduction in the cyclical variability of output. Rolling standard deviations of output growth (year-on-year) show that output growth volatility has declined in the past few years and a variance decomposition analysis shows that the decline in output volatility largely reflects the changes in sectoral composition of GDP and the dominance of the service sector. Reflecting the same structural shift, the amplitude of Hong Kong SAR's business cycles has also declined since the 1980s.

\section{Macroeconomic Implications of Policies in the Mainland on Hong Kong SAR}

7. As Hong Kong SAR becomes more integrated with the Mainland, the potential spillover effects of macroeconomic fluctuations in the Mainland on Hong Kong SAR could increase. An economic slowdown in the Mainland could affect Hong Kong's SAR's economy through a variety of channels including trade links, lower revenues from Mainland tourists to Hong Kong SAR and lower investment earnings. ${ }^{7}$ The likely impact on Hong Kong SAR's economy can be gauged in three ways:

\footnotetext{
${ }^{5}$ The measure of concordance is a simple non-parametric statistic that describes the proportion of time two series are in the same phase (see Harding and Pagan (2002) and Cashin (2004) for more details). The concordance statistics are estimated using year-on-year growth rates over 15-quarter rolling sub-periods. Similar results were arrived at using Hodrick-Prescott filtered cyclical components over 15-quarter rolling sub-periods. These statistics could be influenced by structural breaks, but it is difficult to test this formally since the data span a relatively short period.

${ }^{6}$ Test of the null hypothesis of no association between the Hong Kong SAR and the Mainland's business cycles was strongly rejected for output, consumption, investment and exports, which suggests that the comovement between the two economies cycles is statistically significant and corroborates the results of the contemporaneous concordance ratios that are described above.

${ }^{7}$ Staff analysis presented in Occasional Paper 226 shows that price convergence with the Mainland played an important role in explaining the deflationary process in Hong Kong SAR.
} 
- A restricted partial equilibrium analysis suggests that, if a slowdown in domestic investment growth in the Mainland were to lead to a one-time 10 percentage point decline in Mainland's import growth for domestic consumption, it would have a limited macroeconomic impact on Hong Kong SAR. ${ }^{8}$ For simplicity, imports of textiles and electronics products (which serve as a proxy for processing exports to industrial markets) were assumed to remain unaffected. The impact of such a shock could lower Hong Kong SAR's growth by about $1 / 2$ percentage point, after the multiplier effects of a change in demand on aggregate income are taken into account. The current account surplus would be reduced only marginally since both its imports and exports would be affected almost proportionally.

- The impact of policy tightening in the Mainland on Hong Kong SAR can also be assessed by drawing upon the empirical results on the level of synchronization of the two economies' business cycles. As discussed in Section $\mathrm{C}$ above, although the two economies' output are highly correlated, lower correlations between their consumption and investment variables suggest that the direct impact of macroeconomic tightening in the Mainland is likely to be felt mainly through the effect on Hong Kong SAR's exports.

- Lessons could also be drawn from the impact of previous boom/bust cycles in the Mainland on Hong Kong SAR's economy. During the period 1986-90, the Mainland experienced a hard landing. In 1989-90, Hong Kong SAR's real GDP growth rate declined to an average of 3 percent from an average of 12 percent in 1986-87. In general, the lesson from the impact of previous boom/bust cycles in the Mainland on Hong Kong SAR's economy suggests that the overall impact of a slowdown in the Mainland on Hong Kong SAR might be slightly larger than what the results from the partial equilibrium analysis indicate. ${ }^{9}$

\section{Simulation results on the macroeconomic impact of CEPA on Hong Kong SAR} suggest that the impact of the zero-tariff aspect of the CEPA agreement by itself is likely to be small. This is because the zero-tariff policy in CEPA applies only to direct merchandise goods exports from Hong Kong SAR to the Mainland which account for less than 10 percent of Hong Kong SAR's total exports. ${ }^{10}$ Box I. 1 provides details of the CEPA agreement. The simulation uses the Global Trade Analysis Project (GTAP) model to set tariff rates as zero on 100 percent of direct exports of goods from Hong Kong SAR to the

\footnotetext{
${ }^{8}$ It is estimated that such a decline in the Mainland's imports would be consistent with an initial drop of $5 \frac{1}{2}$ percentage points in its real investment growth and a $4 \frac{1}{4}$ percentage point decline in GDP growth, after multiplier effects are taken into account.

${ }^{9}$ The partial equilibrium analysis discussed above does not take into account the effects a slowdown in the Mainland on Hong Kong SAR that work through financial channels.

${ }^{10} \mathrm{Re}$-exports are the dominant form of exports for Hong Kong SAR and account for over 90 percent of total exports.
} 
Mainland. Table I.1 summarizes the GTAP simulation results. Using the central elasticities in the GTAP model as the baseline scenario, the simulation results show that: ${ }^{11}$

- A zero tariff policy under CEPA will increase Hong Kong SAR's annual GDP by 0.3 percentage point (compared to the baseline of no-CEPA scenario) and increase total employment by about 0.2 percentage point; ${ }^{12}$

- The overall trade balance for Hong Kong SAR will improve by about 0.4 percentage point;

- CEPA will give rise to some welfare gains through four main channels: (i) more efficient resource allocation; (ii) improvements in the terms of trade; (iii) expansion of production endowments and (iv) technology innovation and productivity improvements.

9. However, the direct and indirect impact of the service sector liberalization component of CEPA (including tourism), which is not captured by the GTAP model, is expected to become increasingly significant over time. ${ }^{13}$ The removal of entry barriers to the Mainland is likely to benefit a large number of service industries in Hong Kong SAR, which together account for about 40 percent of GDP. Since CEPA applies to Hong Kong SAR companies regardless of the nationality of their shareholders and investors, overseas companies should find it more attractive than before to use Hong Kong SAR as a regional headquarters location to support their Mainland operations. Thus, CEPA will allow Hong Kong SAR firms to expand their businesses in the Mainland rather than relocate to the Mainland and would attract FDI to Hong Kong SAR. Simulations were conducted in which capital accumulation and productivity variables were shocked as a proxy for assessing the direct impact on Hong Kong SAR of the service sector liberalization component of the CEPA agreement. The results show that the service sector liberalization in CEPA would have a significantly larger impact on Hong Kong SAR than the zero-tariff policy on direct exports of merchandise goods to the Mainland (it would yield almost 3 times the size of the

\footnotetext{
${ }^{11}$ The GTAP model uses the Armington demand elasticities - (i) elasticity of substitution between domestic Mainland goods and imports from Hong Kong SAR, which reflects the trade creation effect of the CEPA FTA for Hong Kong SAR; (ii) elasticity of substitution between imports by country of origin, this elasticity reflects the trade diversion effect as the removal of the tariff on imports from Hong Kong SAR would stimulate those imports to substitute those from the other trading partners for the Mainland. Sensitivity tests reported in Table I. 1 indicate that the simulation results are generally robust to the values chosen for these elasticities.

12 The higher level of GDP comes from the reduction in tariff payments by Hong Kong SAR exporters, the increase in export volumes, the increase in investments in sectors that will become more competitive, and the additional consumer spending by those who experience income growth under CEPA.

${ }^{13}$ Total expenditure by Mainland tourists was HK\$37.8 billion in Hong Kong SAR (about 3 percent of GDP) in 2003. However, this is likely to increase significantly in 2004 and over the medium term, following the relaxation of restrictions on tourist travel from the Mainland to Hong Kong SAR in July 2003 and the launch of the "individual visit" scheme.
} 
estimated impact of the zero-tariff policy on the level of GDP - the sum of the GDP effects in scenarios 6 and 7 of Table I.1). Service sector liberalization in CEPA would also have a positive impact on business confidence in Hong Kong SAR.

\section{Impact of Capital Account Liberalization in the Mainland on Hong Kong SAR}

\section{Hong Kong SAR is well placed to benefit from gradual capital account}

liberalization in the Mainland. While the Mainland authorities still have strict controls on most capital account transactions, over the past couple of years they have taken some steps toward capital account liberalization. As integration deepens, Hong Kong SAR, which is still an important financial gateway to the Mainland, is likely to play an important role in reforming and strengthening the Mainland's capital market since: (i) it has a world class financial infrastructure, and (ii) it is a natural testing ground for the Mainland's liberalization measures.

- Following the lifting of the ban on emigrants' transfer of legitimate assets abroad by nonMainland residents and the restrictions on cross-border transfer of foreign exchange capital by multinationals, portfolio outflows to Hong Kong SAR are likely to increase. Ma and McCauley (2003) estimate, that of the US\$40 billion increase in net claims of Mainland banks on the international banking system (based on data by BIS reporting banks for the period 1999-2001), US\$14 billion flowed through banks located in Hong Kong SAR.

- Another possibility of further capital account liberalization being considered by the Mainland authorities is through the Qualified Domestic Institutional Investor (QDII) scheme. The QDII scheme would allow domestic institutional investors to invest in capital markets abroad which would be a source of liquidity for Hong Kong SAR's stock market.

- Mainland authorities may allow some residents to invest in Hong Kong SAR's property market, which is an important component of the Hong Kong SAR's economy. At present, capital controls have constrained the ability of Mainland residents to acquire property in Hong Kong SAR.

- The addition of the renminbi to Hong Kong SAR's financial infrastructure, in however modest a manner, is of strategic importance to the maintenance of Hong Kong SAR's status as an international financial centre and would enable it to capture international financial intermediation activities denominated in renminbi. The Hong Kong SAR authorities' medium-term goal is to have a real time gross settlement system for the renminbi in Hong Kong SAR.

\section{However, further capital account liberalization in the Mainland could pose some} challenges for Hong Kong SAR.

- Greater exposure of Hong Kong SAR's stock and real estate markets to the Mainland implies that a significant component of Hong Kong SAR's economy will be vulnerable to cyclical and structural shocks emanating from the Mainland. 
- Relatedly, capital flows constitute a potential source of financial sector procyclicality which tends to result in excessive credit growth during booms and a credit crunch during a recession (see Chapter III). Increased capital flows from the Mainland to Hong Kong SAR, which would be largely intermediated through the banking system, could influence financial sector procyclicality in Hong Kong SAR.

12. More generally, as financial integration between the two economies deepens, there would be further challenges for financial sector supervision and regulation in Hong Kong SAR as Mainland and Hong Kong SAR banks increasingly operate in each others' territories. The need for better coordination of cross-border supervision would therefore become increasingly important.

\section{E. Conclusions}

13. This chapter has documented the economic impact on Hong Kong SAR of the ongoing integration between Hong Kong SAR and the Mainland and analyzed the likely impact of policy developments in the Mainland on Hong Kong SAR. The chapter's main conclusions are as follows:

- Increased integration between the two economies has deepened across various sectors over the past decade and this has led to significant changes in structure of Hong Kong SAR's economy.

- As integration has progressed, the business cycles in Hong Kong SAR and the Mainland have become increasingly synchronized, which implies that macroeconomic fluctuations in the Mainland could have significant spillover effects on Hong Kong SAR.

- Hong Kong SAR stands to benefit from the recently signed free trade agreement between the two economies (CEPA) and the gradual capital account liberalization in the Mainland. At the same time, capital account liberalization in the Mainland could also give rise to some challenges for Hong Kong SAR as greater exposure of Hong Kong SAR's stock and real estate markets to the Mainland implies that a significant component of Hong Kong SAR's economy will be vulnerable to cyclical and structural shocks emanating from the Mainland. 


\section{References}

Bank of International Settlements, 2003, "China’s Capital Account Liberalization: International Perspectives,”. BIS Papers No. 15 (April).

Baxter, Marianne, 1991, "Business Cycles, Stylized Facts and the Exchange Rate Regime: Evidence from the United States," Journal of International Money and Finance, Vol. 10, pp: 71-88.

Cashin, Paul, 2004, “Caribbean Business Cycles," IMF Working Paper 04/136 (Washington: International Monetary Fund).

Harding, Don and, Pagan, Adrian, 2002a, "Dissecting the Cycle: A Methodological Investigation," Journal of Monetary Economics, Vol. 49, pp: 365-81.

Hertel, Thomas, 1997, Global Trade Analysis: Modeling and Applications (Cambridge: University Press).

Kawasaki, Keniche, 2004, "The Impact of Free Trade Agreements in Asia," METI on recent developments in Japan's bilateral trade negotiations.

Kose, M. Ayhan, Prasad, Eswar, and Terrones, Marco, 2003, "Volatility and Comovement in a Globalized World Economy: An Empirical Exploration," IMF Working Paper 03/246 (Washington: International Monetary Fund). 


\section{Box I.1: The Closer Economic Partnership Arrangement-Free Trade Agreement between Hong Kong SAR and the Mainland}

The closer economic partnership arrangement (CEPA) that was signed in June 2003 and became effective January 1, 2004 presents significant opportunities for Hong Kong SAR. The second phase of CEPA was signed in August 2004. CEPA gives Hong Kong SAR substantial long-term advantages compared to the Mainland's commitments to other countries under the WTO. Specifically:

- On January 1, 2004, goods from Hong Kong SAR that fell under 273 Mainland product codes (equivalent to 90 percent of Hong Kong SAR's direct exports to the Mainland — and which excludes re-exports) became eligible for a zero-tariff treatment under CEPA.

- On January 1, 2006, the remaining products will also be given a zero-tariff treatment.

- Market access under CEPA is wider than under the Mainland's WTO commitments and includes several sectors including trade in goods, services and investment promotion.

- Many of the trading quotas imposed on Hong Kong firms by the Mainland would also be lifted under CEPA.

The service sector in Hong Kong SAR stands to benefit the most from CEPA, including through the lowering of entry barriers.

- 18 service sectors are eligible for favorable treatment under CEPA (including telecommunications, banking, insurance and management consultancy and other sectors that were not included in the Mainland's WTO commitments); additional service sectors were added to the CEPA list in August 2004.

- CEPA lowers the minimum assets requirement for banks planning to open branches in the Mainland from US\$20 billion to US\$6 billion, thus making most local banks eligible for it.

- It relaxes equity share restrictions for foreign investors in the service sectors.

CEPA's rules of origin are less stringent than those set under similar free trade agreements. Manufacturing firms are required to have only 30 percent of their value added in Hong Kong SAR in order to qualify for CEPA's benefits. Although labor costs are relatively high it may nevertheless be profitable to carry out high value added processes-especially those with intellectual property content_-given the zero tariff, and low tax rates in Hong Kong SAR.

CEPA also includes a liberalization of the Mainland tourist visa scheme (allowing individual, rather than just group visits) that resulted in an immediate surge in tourist arrivals from the Mainland to Hong Kong SAR. 


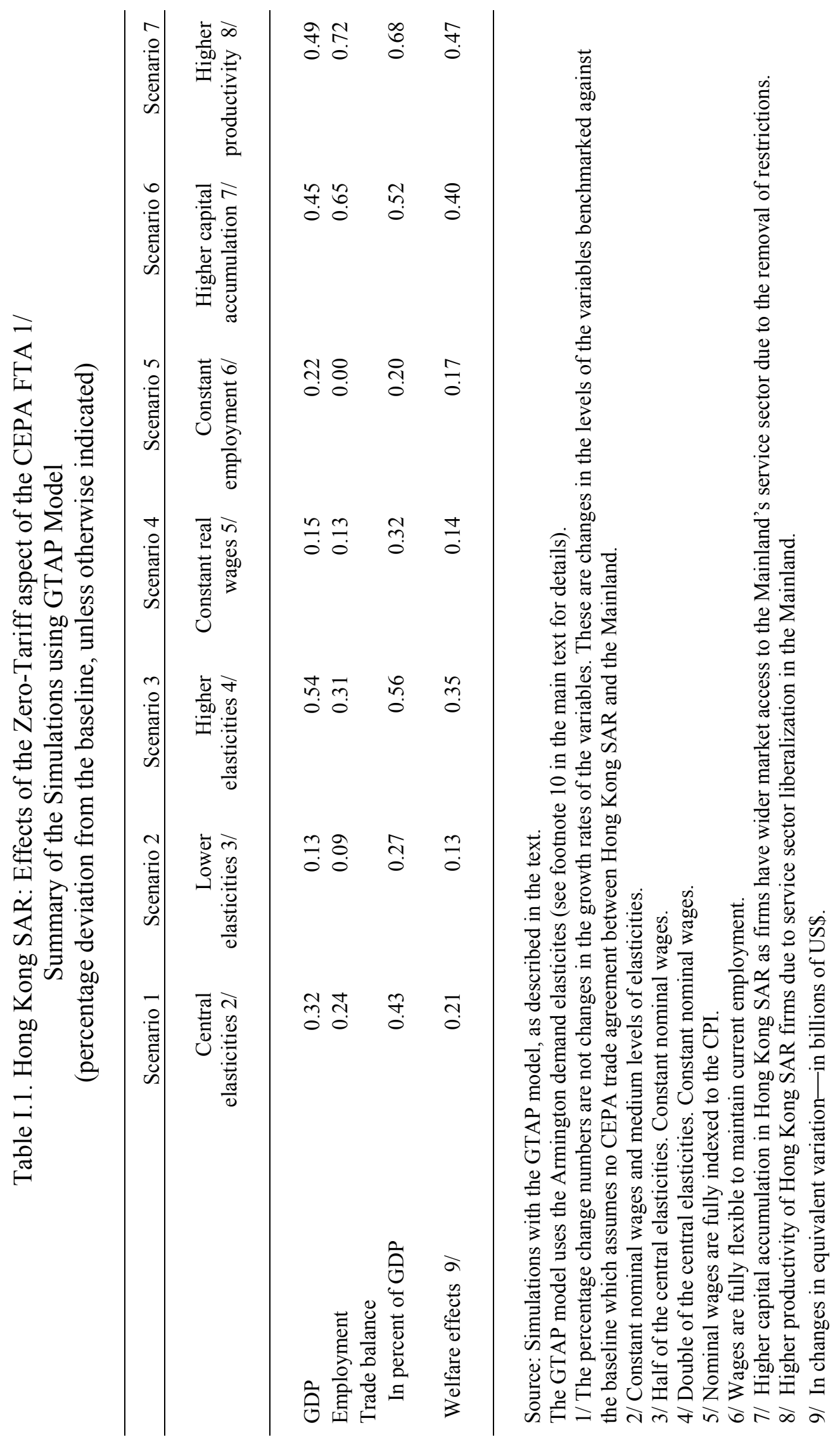


Figure I.1. Linkages between Mainland China and Hong Kong SAR and their Macroeconomic effects
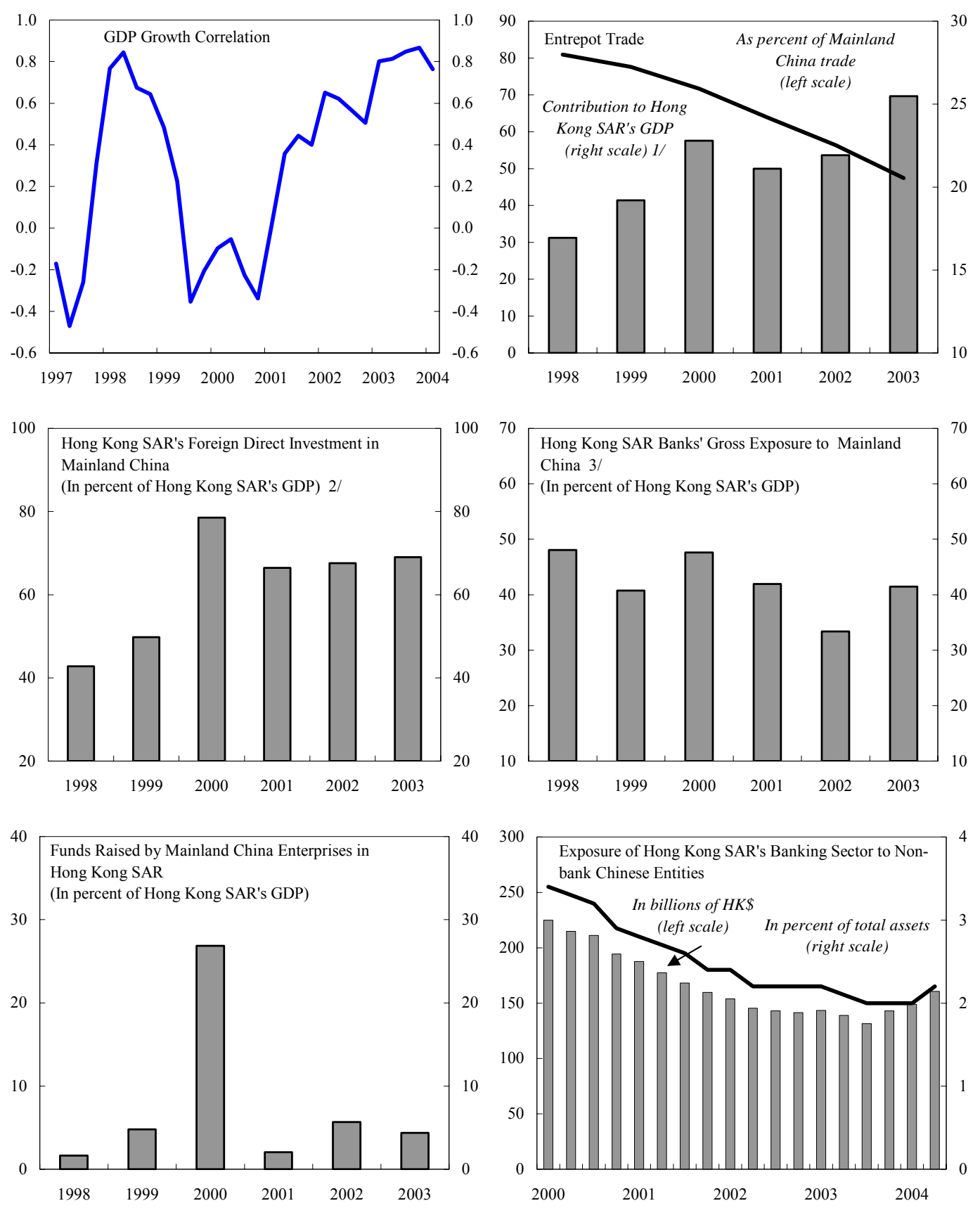

Source: Data provided by the Hong Kong SAR authorities, CEIC database, and staff estimates.

1/. Part of the recent increase in the contribution of entrepot trade to Hong Kong SAR's GDP reflects the increase in re-export margins. 2/. Includes FDI in Mainland China by foreign enterprises based in Hong Kong SAR. However, it probably also includes FDI that is "round tripped" via Hong Kong SAR and back to Mainland China to take advantage of the favorable tax treatment for foreign firms.

3/. Gross exposure as defined here has a broader coverage - it includes claims and liabilities of Hong Kong SAR banks to both banks and non-bank entities in the Mainland. 
Figure I.2. Hong Kong SAR and Mainland China: Degree of Concordance between the Growth Rates of GDP and its Components
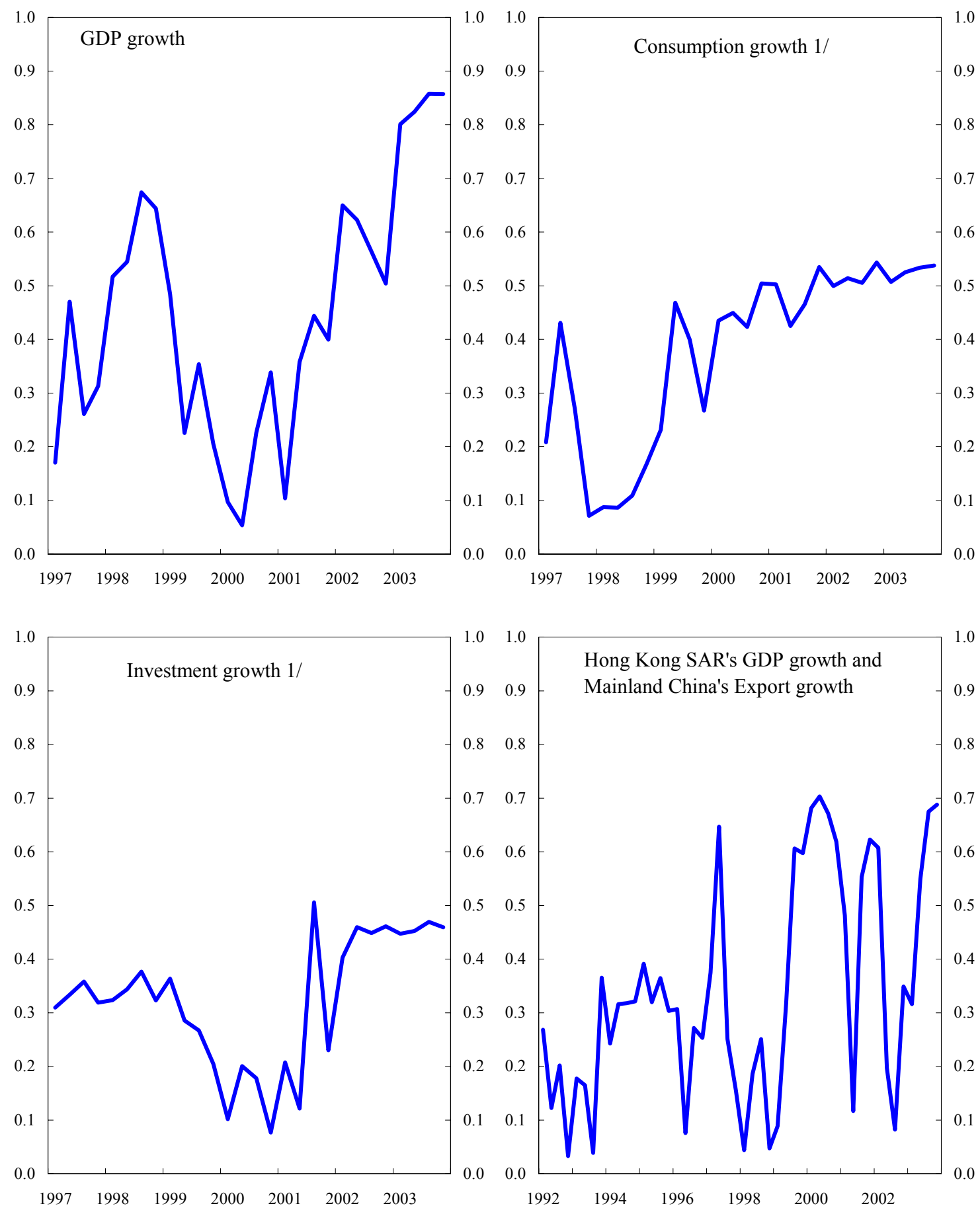

Sources: CEIC database and staff estimates.

$1 /$ The data on quarterly real consumption and investment for China are staff estimates.

2/ Concordance ratios based on four quarter growth rates and a rolling window of 15 quarters. 
Figure I.3. Hong Kong SAR and Mainland China: Degree of Concordance between Financial Market Indicators
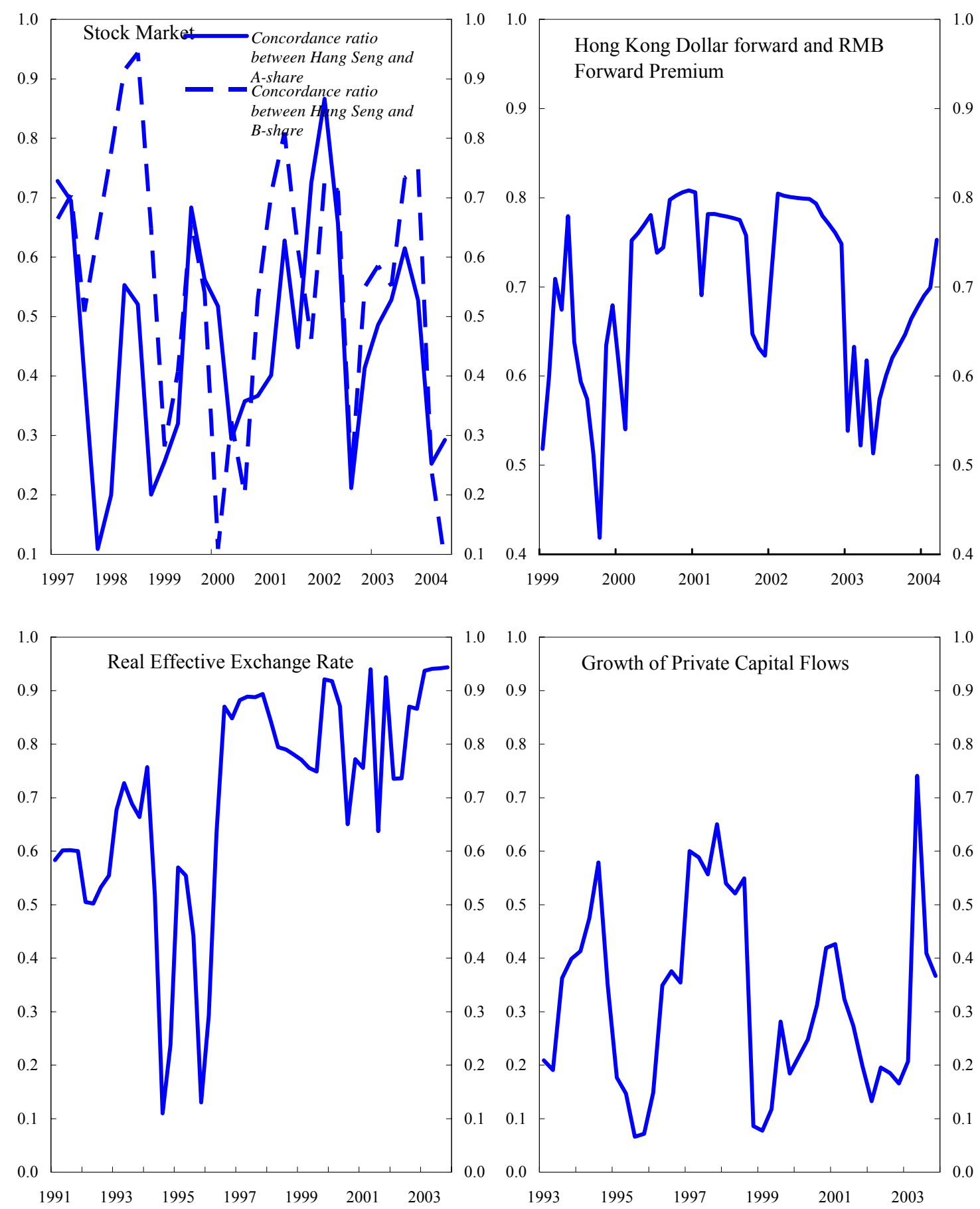

Sources: IMF, Information Notice System, CEIC database, and staff estimates. 


\section{Hong Kong SAR’s CurRency BoArd Under Strong-Side Pressures ${ }^{1}$}

\section{A. Introduction}

1. Following a prolonged period of weak-side pressures on the Hong Kong dollar, significant strong-side pressures emerged in the second half of 2003. The combination of slow growth, rising budget deficits, high unemployment, and persistent deflation had resulted in downward pressure on the local currency during most of the post-Asian crisis period. These factors were compounded by the impact of SARS. Weak-side pressures began to ease with the announcement of a package of growth-enhancing measures from the Mainland in mid-2003 and the broadening of the global recovery. The reversal of sentiment was completed following market reaction to the G-7 Communiqué of September 2003, which was interpreted as signaling broad-based strong-side pressures across Asian currencies and contributed to the end of weak-side pressures on the Hong Kong dollar.

2. To the surprise of the market, the Hong Kong Monetary Authority (HKMA) responded to the burst of strong-side pressures by letting the Hong Kong dollar spot rate appreciate below the linked rate. Since the adoption of "technical" measures in September 1998 designed to strengthen the currency board, the spot rate for the Hong Kong dollar had not been allowed to stray more than one basis point below the linked rate (currently HK\$7.8 per U.S. dollar). While the measures included a commitment by the HKMA to buy Hong Kong dollars at the linked rate, there was no such commitment on the strong side - that is, the currency board has the possibility of being "asymmetric." In the event, on September 22, 2003 the spot rate appreciated to HK\$7.705 per U.S. dollar, or by $1 \frac{1}{4}$ percent.

3. There was some uncertainty in the market in the ensuing period, but the HKMA was ultimately successful in bringing the spot rate back to the linked rate. The market eventually came to a fuller understanding of the potential asymmetry of the exchange rate regime, and the volatility in the local foreign exchange market soon abated, including in response to the HKMA's intermittent sales of Hong Kong dollars aimed at nursing the spot rate back to the link and injecting a degree of constructive ambiguity into the process. By April 2004, the spot rate had returned to the linked rate. However, significant strong-side pressures re-emerged in late 2004, including an unprecedented large discount in the forward market (Figure II.1). ${ }^{2}$

4. This paper analyzes the initial episode of strong-side pressures on the Hong Kong dollar and, in particular, the HKMA's response. After reviewing the history and institutional set-up of the currency board (Section B), and the events of late 2003

\footnotetext{
${ }^{1}$ Prepared by Paul F. Gruenwald, Resident Representative, Hong Kong SAR.

${ }^{2}$ In the Hong Kong dollar forward market, a discount implies expectations of a numerically lower, or more appreciated, exchange rate.
} 
(Section C), an attempt is made to model the trade-offs faced by the HKMA in the presence of strong-side pressures on the Hong Kong dollar (Section D and the Appendix). The model shows that, under certain conditions, it may be optimal - in the sense of improving the credibility of the currency board - for the HKMA to allow strong-side pressures to feed through to the spot rate. ${ }^{3}$ This result holds when the benefits from generating constructive ambiguity outweigh the variable cost of straying too far from the link plus the fixed cost of temporarily deviating from the link. Section E concludes.

\section{B. Hong Kong SAR's Currency Board: A Primer ${ }^{4}$}

\section{How the currency board works}

5. In Hong Kong SAR's currency board regime, both the flow and stock of the monetary base are backed fully by foreign reserves. The monetary base currently comprises: (i) notes and bills in circulation, (ii) the balances of the clearing accounts of banks kept with the HKMA - the "aggregate balance," and (iii) Exchange Fund bills and notes issued by the HKMA on behalf of the government. The currency board matches changes in each of these components with changes in foreign reserves. Moreover, at end-November 2004, the stock of foreign assets in the Exchange Fund stood at US $\$ 125$ billion, more than three times the monetary base. These excess reserves stem from the inclusion into the Exchange Fund of the government's accumulated fiscal surpluses and the Land Fund balance (and accumulated profits thereupon).

6. The "action" in the currency board takes place in the aggregate balance, and adjustment is effected through interest rate movements generated by changes in liquidity conditions in the interbank market. This reflects an important feature in Hong Kong SAR's currency board: notes and coins in circulation are not transferable with the aggregate balance, although each of these components is individually backed by foreign reserves. ${ }^{5}$ Therefore, note arbitrage plays little or no role in the adjustment process as the use of banknotes is limited to the settlement of retail transactions; the much larger wholesale transactions are settled through the aggregate balance. As a result, there is an enormous amount of potential "leverage" in the aggregate balance meaning that small changes in this

\footnotetext{
${ }^{3}$ The justification for this assumption is discussed in section D.

${ }^{4}$ This section borrows liberally from Yam (1998). An overview of the currency board's two decade history appears in Box II.1.

${ }^{5}$ The HKMA acknowledges that this is a delicate question. The main risk of letting banks place notes with the currency board and receive value in the clearing account is that this could give the impression that notes are not directly backed by foreign reserves, thereby potentially undermining confidence in the currency board (Yam, 1998, p. 13).
} 
variable may generate large changes in interbank interest rates, particularly when weak-side pressures drive the aggregate balance to minimal levels. ${ }^{6}$

7. The interest rate arbitrage mechanism ensures that Hong Kong SAR's currency board is self-regulating. This characteristic, at least in the pure version of the currency board, underscores the rule-based nature of the regime. The stylized adjustment for strongside pressures occurs as follows (the weak-side adjustment is symmetric). A desired capital inflow leads market participants to buy the Hong Kong dollar, putting pressure on the exchange rate to appreciate. In response, the currency board sells Hong Kong dollars, the monetary base expands, and the increase in liquidity drives local interest rates lower. This results in a larger interest rate differential against the Hong Kong dollar vis-à-vis the U.S. dollar, lowering demand for the local currency, thereby causing capital inflows to stop, which equilibrates the system. ${ }^{7}$

\section{Changes to the currency board as a result of the Asian financial crisis}

\section{A number of major attacks on the Hong Kong dollar in 1997-98 highlighted the} adjustment mechanism as interest rates spiked sharply. These episodes featured widespread short position taking against the Hong Kong dollar, and banks ran the aggregate balance down to very low levels. As a result of the leverage of the aggregate balance noted above, interbank rates shot up to almost 50 percent in one episode (and about 20 percent in the others), triggering an eventual sale of U.S. dollars and a reconstitution of the aggregate balance. While the flow constraint of the currency board was respected at all times during these episodes and the adjustment mechanism brought about the desired portfolio rebalancing, there were calls from the community to change the way the currency board operated with a view to relieving somewhat the pain of sharp interest rates rises.

9. In response to the major attacks on the Hong Kong dollar, in September 1998 the HKMA introduced a number of technical measures intended to strengthen the operation of the currency board (Box II.2). The measures were designed to demonstrate the government's commitment to the Linked Exchange Rate System (LERS), and dampen interest rate volatility which, in the view of the authorities, had been excessive and potentially destabilizing. The most important of these measures were to (i) clarify the "weakside convertibility undertaking" whereby the HKMA is obliged to buy Hong Kong dollars at the linked rate and (ii) specify simplified rules regarding access to the HKMA's discount

\footnotetext{
${ }^{6}$ This leverage is magnified by the absence of reserve requirements in Hong Kong SAR.

${ }^{7}$ There exists the possibility that interest rate arbitrage might not occur if U. S. dollar interest rates are "too low." This arises since the HIBOR is bounded below by zero and the maximum interest rate differential may be insufficient to generate adequate demand for the U.S. dollar. However, local analysts noted that, even with U.S. short-term rates at the recent low of 1 percent, the differential would be large enough to arbitrage.
} 
window using Exchange Fund bills and notes (which were thereafter included in the monetary base) in order to provide additional liquidity in times of financial stress. ${ }^{8}$

10. The 1998 measures formalized an implicit asymmetry in the currency board operations, which gives the HKMA discretion on the strong side of the link. This flexibility was, in a sense, granted by omission since there was no specification of a strongside convertibility undertaking (i.e., a requirement to sell Hong Kong dollars at the linked rate). This reflected, in large part, the concern of market participants at that time regarding weak-side risks rather than strong-side risks. While information on the lack of a strong-side undertaking was in the public domain, the potential for the currency board to be asymmetric was not well understood as evidenced by the events of late 2003 . This may have reflected the almost complete lack of sizeable strong-side pressures on the Hong Kong dollar since the measures were adopted, which meant that the potential asymmetry of the regime had never come into play.

\section{The Initial Episode of Strong-side Pressures on the Hong Kong Dollar}

\section{Prior to the events of September 2003, a play on the Hong Kong dollar was seen}

by the market as a one-way bet. Traders priced in a weakening of the Hong Kong dollar in the forward market, and there was widespread short position taking against the currency. ${ }^{9}$ Sentiment toward Hong Kong SAR was tepid and talk of breaking the "peg"- -which was seen as largely responsible for the poor state of the economy-was common.

\section{The market was caught off guard by the HKMA's initial "nonintervention" in} response to appreciation pressures. Using for the first time its discretion on the strong side of the linked rate, the HKMA elected initially not to fully meet the demand for Hong Kong dollars (i.e., act as a pure currency board) as market forces threatened to push the spot rate below the linked rate. Part of the HKMA's strategy was to punish those who had sold the currency short by not providing a one-way bet and "not bailing out currency speculators.",10 The consequent strengthening of the Hong Kong dollar led to attempts by market players to unwind (cover) their short positions by trying to purchase the local currency; reportedly, around one-third of the short contracts were unwound quickly. There were also some fears in the community that the currency board may have been abandoned-i.e., that the Hong Kong dollar had been floated. For its part, the HKMA did not make an immediate announcement.

\footnotetext{
${ }^{8}$ As a result, Exchange Fund bills and notes became relatively more valuable to banks, who now hoard this paper.

${ }^{9}$ This also led to a popular trade called the "convergence play," where a short position in the Hong Kong dollar was used to fund a long position in the Chinese renminbi on the view that the nominal exchange rates of the two currencies would equalize.

${ }^{10}$ Yam, Joseph, 2003, “Sentiment on the Hong Kong Dollar,” Viewpoint (a weekly on-line column) on http://www.info.gov.hk/hkma/eng/viewpt/index.htm), October 2.
} 
13. When the HKMA did begin to sell Hong Kong dollars, the aggregate balance jumped to the unprecedented amount of HK\$55 billion (Figure II.2). ${ }^{11}$ Most of this increase took place from December 2003 to January 2004. Consistent with the currency board's flow constraint, an increase in the aggregate balance is, by definition, the counterpart to foreign exchange purchased from banks. It is important to underscore that while banks sold foreign currency to the currency board at rates on the strong side of the link, it is only possible to exit from the aggregate balance (buy U.S. dollars) at the linked rate, meaning that the currency board makes a profit on these transactions. ${ }^{12}$

\section{The HKMA was able to nurse the spot exchange rate back to the linked rate.}

This was achieved by April 2004 following a strategy of seemingly randomized interventions: selling the local currency in differing quantities, at different rates and in different markets. Subsequently, the weak-side convertibility undertaking came into play a number of times, and the aggregate balance declined to HK\$3 billion by end-September 2004. Strong-side pressures on the Hong Kong dollar re-emerged in October 2004 reflecting renewed expectations of a strengthening of the Chinese renminbi. By end-November 2004, the spot rate was $2 \frac{1}{2}$ basis points on the strong side of the link, the forward discount had risen to almost 15 basis points, and the aggregate balance had climbed back to HK\$14 billion.

15. Overall, the HKMA appears to have achieved its objectives in responding to the initial episode of strong-side pressures. Confidence in the LERS remains high. Moreover, most of the Hong Kong dollar short positions have reportedly been unwound, and the market has become aware that the local currency is not a one-way bet. We now consider these issues in a more formal framework.

\section{The Model}

16. This section presents a graphical exposition of a simple, one-shot, partial equilibrium model intended to highlight the trade-offs faced by the HKMA in responding to strong-side pressures in the local foreign exchange market. The details of the model, and extensions, appear in the Appendix.

\footnotetext{
${ }^{11}$ The only other comparable event took place in late 1999 in response to fears over the Y2K phenomenon, when the aggregate balance rose sharply to about HK $\$ 8$ billion.

${ }^{12}$ Agents needing to cover short positions also faced a loss. They initially sold Hong Kong dollars at rates on the weak-side of the link (anticipating a depreciation) and had to close those positions by purchasing Hong Kong dollars on the strong-side of the link.
} 
17. It is assumed that the sole objective of the monetary authorities is to maximize the credibility of the LERS. ${ }^{13}$ While this can arguably be achieved by following a pure currency board approach at all times, recent events suggest that it may be optimal to judiciously deviate from the link in the event of strong-side pressures. ${ }^{14}$ In order to keep the analysis tractable, the model limits the authorities' actions to a binary strategy set. Specifically, in response to a capital inflow stemming from an increase in the demand for Hong Kong dollar liquidity, the monetary authority can either (i) sell Hong Kong dollars at the linked rate (act as a pure currency board), or (ii) not intervene and let the exchange rate appreciate for a fixed time period before bringing the spot rate back to the link. ${ }^{15} \mathrm{An}$ extension allowing for partial intervention is discussed below.

\section{The monetary authority must weigh the various costs and benefits to the} credibility of the currency board from choosing to temporarily deviate from the linked rate. In what follows, the unit of measurement can be thought of as the increase in credibility relative to a pure currency board. ${ }^{16}$ Therefore, acting like a pure currency board is assumed to give the monetary authority a payoff of zero. If a positive payoff can be achieved by deviating from the linked rate for a fixed time period, then it will be optimal to do so. ${ }^{17}$ It is useful to separate the potential payoff into variable and fixed components.

- Variable benefits and costs. The variable benefit is the gain to credibility from the generation of constructive ambiguity or the creation of a two-way bet. This benefit is assumed to taper off as the spot rate moves away from the link. The variable cost is the loss of credibility to the currency board from the possibility that agents begin to make consumption and investment decisions based on a perceived new exchange rate (regime); this cost increases as the spot rate moves away from the linked rate. Combining these two effects gives a net benefit function with an inverted U-shape (Figure II.3).

${ }^{13}$ Of note, there is no output in the model since the magnitude of the exchange rate movements under consideration is assumed to have negligible effects on real variables. Therefore, unlike in the Barro-Gordon model, there is no time inconsistency problem.

${ }^{14}$ In practice, the HKMA often does not intervene when the spot rate moves away from the linked rate by small amounts on the strong side, preferring to let the market work.

15 The term "currency board" is maintained in this discretionary framework since both the flow and stock constraints (noted in Section B) were observed at all times.

${ }^{16}$ While the level of credibility can play an indirect role in the monetary authority's decision whether or not to temporarily deviate from the link (see below), it is not explicitly discussed in the current framework.

${ }^{17}$ The optimal amount of time spent away from the linked rate is endogenous - see the Appendix. This issue will not be discussed in the main text. 
- Fixed costs. As in the discretionary "escape clause" literature (Obstfeld, 1991) there is a fixed cost to credibility from temporarily suspending the defense of the linked rate; this cost is inversely related to the level of credibility of the exchange rate regime. The idea is that a credible monetary authority may be able to incur such a cost in order to temporarily pursue other goals (Eichengreen, 1998). ${ }^{18}$ This fixed cost is considered to be larger on the weak-side of the link, where the temptation to reflate is greater and the ability to bring the spot rate back to the link is more difficult. Indeed, it is assumed that the fixed cost on the weak-side is so large as to preclude any consideration of temporarily weakening the spot rate.

19. Deviating from the linked rate on the strong side will be optimal only if the net benefits from doing so exceed the fixed cost over some interval of potential exchange rate shocks (Figure II.4).The intuition behind this result is straightforward: relatively small potential exchange rate shocks do not generate sufficient variable benefits to cover the fixed cost of deviating from the link. On the other hand, relatively large potential shocks to the exchange rate carry a large variable cost since the penalty to credibility increases as we move farther away from the link. Given the inverted U-shape of the net benefit function, an optimal nonintervention strategy - if it exists - will therefore hold for some (continuous) intermediate range of exchange rate shocks. As a corollary, if the fixed cost is higher than the net benefit over all potential exchange rate shocks, then it will always be optimal for the monetary authority to act like a pure currency board.

\section{The main result and intuition of the model hold for two natural extensions:}

- Partial intervention. The "on-off" strategy set of the main model is clearly unrealistic. Allowing the monetary authority to partially absorb part of the capital inflow and, by extension, curb the potential appreciation of the exchange rate, changes the result that a potential exchange rate shock can be too large to justify not acting like a pure currency board. From Figure II.4, the optimal response of the monetary authorities for large shocks - defined as those that would lead to the exchange rate strengthening beyond the peak of the net benefit function - would be to partially intervene so as to maximize the net benefit function. (This assumes, of course, that a positive payoff would result.)

- Closed form solution. Adding additional specificity to the model using common, simple functional forms for the variable benefit and cost functions provides a direct relationship between the existence of a nonintervention strategy and the "productivity" of creating a two-way bet (see Appendix). The intuition is that a large build-up of short positions increases the likelihood that temporarily deviating from the link would bolster the credibility of the currency board.

${ }^{18}$ Eichengreen studies whether a credible monetary authority can temporarily suspend its defense of a fixed exchange rate to facilitate welfare-enhancing financial sector reform. 


\section{E. Conclusions}

21. The strong-side pressures on the Hong Kong dollar that emerged in late 2003 allowed the HKMA to successfully employ for the first time its discretion under the currency board arrangement. While letting the spot exchange rate deviate from the link on the strong side surprised the markets and led to a period of uncertainty, it was also successful in producing a degree of constructive ambiguity by making the Hong Kong dollar a two-way bet. This arguably enhanced the credibility of the LERS.

\section{This paper presented a framework showing that temporary nonintervention} under a currency board regime in the face of strong-side pressures may be optimal under some circumstances. The main result is that the decision whether to intervene (act like a pure currency board) or not depends on the relative sizes of (i) the variable net benefits accruing from the creation of constructive ambiguity and (ii) the fixed costs of temporarily deviating from the link. The model can be extended to accommodate partial intervention, and to generate a relationship between the "stock" of weak-side pressure and the productivity of letting the spot rate strengthen. ${ }^{19}$

\section{Finally, it remains to be shown whether the results of the simple model} presented here hold in a more general framework. The robustness of the model could be verified by examining: (i) a repeated game between the HKMA and the market; and (ii) a general equilibrium approach including the incorporation of real effects. The extent to which the model is robust, and whether other jurisdictions with currency board-type regimes could successfully employ such an asymmetric approach, is left for future research. Even if the model is shown to be robust under these circumstances, an optimal nonintervention strategy is likely to exist only for those countries whose exchange rate regimes enjoy a high level of credibility.

${ }^{19}$ An issue not explored in this paper is whether the current, asymmetric currency board model would be superior to a two-sided convertibility undertaking. The finding that the productivity of creating a two-way bet is important suggests that the payoff from an asymmetric approach could potentially dominate that of a hard-edged, two-sided system. 


\section{References}

Eichengreen, Barry, 1998, "Exchange Rate Stability and Financial Stability," Open Economies Review Supplement, June.

Hong Kong Monetary Authority, "Reports on Currency Board Operations," Quarterly Bulletin, various issues. Available via the Internet: http://www.info.gov.hk/hkma/index.htm.

Hong Kong Monetary Authority, 1998, "Strengthening of Currency Board Arrangements in Hong Kong,” Quarterly Bulletin, November.

Hong Kong Monetary Authority, 2000, Hong Kong’s Linked Exchange Rate System, November. Available via the Internet: http://www.info.gov.hk

Ma, Yue, Guy Meredith, and Matthew S. Yiu, 2002, “A Currency Board Model for Hong Kong," Hong Kong Institute for Monetary Research Working Paper No. 1/2002, January.

Meredith, Guy, 1999, “Liquidity Management Under Hong Kong's Currency Board Arrangements," prepared for the International Workshop on Currency Boards: Convertibility, Liquidity Management and Exit, October.

Obstfeld, Maurice, 1991, "Destabilizing Effect of Exchange Rate Escape Clauses," NBER Working Paper No. 3603, January.

Obstfeld, Maurice, and Kenneth Rogoff, 1999, Foundations of International Macroeconomics, MIT Press.

Spencer, Michael, 2003, “Why the Peg Should Go,” Deustche Bank, January 29.

Yam, Joseph, 1998, Review of Currency Board Arrangements in Hong Kong, Hong Kong Monetary Authority, December.

Yam, Joseph, "Viewpoint, " [online serial, various issues]. Available via the Internet: http://www.info.gov.hk/hkma/index.htm. 


\section{The Model}

This Appendix presents the details of the model, as well as an example using common functional forms, which generates a closed form solution.

\section{Main model}

Suppose the monetary authority faces the following optimization problem:

$$
\begin{gathered}
\max U=\left\{X(s, t)-Y(s, t)-c^{s}, 0\right\} \\
\text { s.t. } e_{t} \in\{\bar{e}-s, \bar{e}\}
\end{gathered}
$$

where:

- $\mathrm{U}$ is the additive and separable payoff function, interpreted as the net gain to the monetary authority compared with not temporarily deviating from the link, which carries a payoff of zero by construction.

- $e_{t}$ is the exchange rate measured as the number of local currency units per unit of foreign currency; $\overline{\mathrm{e}}$ is the linked exchange rate.

- $\mathrm{s}$ is the potential change to the nominal exchange rate stemming from a beginning-of-theperiod capital inflow shock. If the monetary authority chooses not to intervene, then the exchange rate appreciates to $\overline{\mathrm{e}}-\mathrm{s}$; if it does intervene, then $\mathrm{e}_{\mathrm{t}}=\overline{\mathrm{e}}$.

- $t$ is the amount of time the monetary authority allows the spot rate to deviate from $\overline{\mathrm{e}}$. The optimal time period, $\mathrm{t}^{*}$, is determined endogenously in this model.

- $\mathrm{X}(\mathrm{s}, \mathrm{t})$ is the variable benefit from deviating from the linked exchange rate by amount $\mathrm{s}$ for time t. $X_{\mathrm{s}}>0, \mathrm{X}_{\mathrm{ss}}<0 ; \mathrm{X}_{\mathrm{t}}>0, \mathrm{X}_{\mathrm{tt}}<0$; and $\mathrm{X}(0,0)=0$.

- $\mathrm{Y}(\mathrm{s}, \mathrm{t})$ is the variable cost from deviating from the linked exchange rate by amount $\mathrm{s}$ for time t.. $\mathrm{Y}_{\mathrm{s}}>0, \mathrm{Y}_{\mathrm{ss}}>0 ; \mathrm{Y}_{\mathrm{t}}>0, \mathrm{Y}_{\mathrm{tt}}>0$; and $\mathrm{Y}(0,0)=0$.

- $\quad \mathrm{c}^{\mathrm{i}}(\mathrm{i}=\mathrm{S}, \mathrm{W})$ is the one-off fixed cost to the monetary authority of deviating from the linked rate on the strong $(\mathrm{S})$ and weak $(\mathrm{W})$ sides. As with $\mathrm{X}$ and $\mathrm{Y}, \mathrm{c}(0)=0 . \mathrm{c}^{\mathrm{W}}>>0$; the cost of deviating on the weak-side of the linked rate is assumed to be so large that it is never optimal for the monetary authority let the exchange rate weaken above $\bar{e}$.

It will be useful define the net benefit function by the following transformation:

$$
Z(s, t)=X(s, t)-Y(s, t)
$$

$\mathrm{Z}$ (.) be can simplified by solving for the reaction function $\mathrm{t}^{*}(\mathrm{~s})$. That is, given any $\mathrm{s}>0$, the monetary authority will always choose $t$ so as to maximize $Z($.). We can then write the optimal net benefit function as $\mathrm{Z}(\mathrm{s}, \mathrm{t} *(\mathrm{~s}))$, which depends only on $\mathrm{s}$. 
Noting that, by assumption, $Z^{*}$ has a unique, well-defined maximum, we can now state the main result of the model:

- If $\mathrm{c}^{\mathrm{S}}<\max \mathrm{Z}^{*}$, then there exists some continuous interval $\left(\mathrm{s}_{\text {low }}, \mathrm{s}_{\text {high }}\right)$ where $\mathrm{U}^{*}>0$. For $\mathrm{s}$ in this interval, it will be optimal to let $\mathrm{e}_{\mathrm{t}}=\overline{\mathrm{e}}-\mathrm{s}$ for time period $\mathrm{t}^{*}(\mathrm{~s})$.

- In contrast, if $\mathrm{c}^{\mathrm{S}}>\max \mathrm{Z}^{*}$ the solution for the monetary authority will always be to act as a "pure" currency board with passive intervention. Under these conditions, $\mathrm{U}^{*}=0$ (since $\mathrm{Z}^{*}-\mathrm{c}^{\mathrm{S}}$ is negative).

Thus, $\mathrm{U}^{*}$ will be zero for low and high values of $\mathrm{s}$, and will exceed zero for intermediate values provided that $\mathrm{c}^{\mathrm{S}}<\max \mathrm{Z}^{*}$.

\section{Example}

Consider the model using the following functional forms:

$\mathrm{X}(\mathrm{s}, \mathrm{t})=\mathrm{A} \mathrm{s}^{1 / 2} \mathrm{t}^{1 / 2}$ and $\mathrm{Y}(\mathrm{s}, \mathrm{t})=\mathrm{s}^{2}+\mathrm{t}^{2}$, so that the net benefit function is:

$$
Z(s, t)=X(s, t)-Y(s, t)=A s^{1 / 2} t^{1 / 2}-s^{2}-t^{2}
$$

To find $t^{*}$ for any given $s$, set $d Z / d t=0$ and solve for $t$, which yields: $t^{*}=(A / 4)^{2 / 3} s^{1 / 3}$.

Substituting this result into $Z($.$) yields: Z\left(s, t^{*}(s)\right)=3(A / 4)^{4 / 3} s^{2 / 3}-s^{2}$

Note that $\mathrm{dZ} / \mathrm{ds}>(<) 0$ when $\mathrm{A} / 4>(<) \mathrm{s}$.

Evaluating this function at its maximum: $\mathrm{s}=\mathrm{A} / 4$, yields $\mathrm{Z}^{\max }\left(\mathrm{s}, \mathrm{t}^{*}\right)=2[\mathrm{~A} / 4]^{2}$.

This implies that it will only be optimal for the monetary authority to deviate from the linked rate on the strong side if

$$
\mathrm{c}^{\mathrm{S}}<2[\mathrm{~A} / 4]^{2}
$$

so that the threshold value of $\mathrm{c}^{\mathrm{S}}$ is increasing in $\mathrm{A}$.

The parameter $\mathrm{A}$ - which rotates the gross benefit function $\mathrm{X}$ upward - can be interpreted here as the productivity of creating constructive ambiguity in the form of a two-way bet on the currency. This follows from the gross benefit function taking the Cobb-Douglas form $\mathrm{X}(\mathrm{s}, \mathrm{t})=\mathrm{A} \mathrm{s}^{1 / 2} \mathrm{t}^{1 / 2}$ where $\mathrm{A}$ carries the standard interpretation as a productivity parameter. In this light, a higher A could plausibly be attributed to a larger size of short positions built up against the Hong Kong dollar. A possible extension of the model could therefore be to endogenize A with the interpretation of it being a type of "bad" capital. 
Box II.1. The Evolution of Hong Kong's Currency Board Arrangements from its Inception through the Asian Crisis

In the initial structure of the currency board, the aggregate balance was not under the control of the monetary authority. ${ }^{1}$ At that time, the interbank clearing system was run by a commercial bank, the Hong Kong and Shanghai Banking Corporation Limited (HSBC). No agreement existed to ensure that the aggregate balance was subject to the discipline of the currency board, leaving HSBC in a privileged position of being able to create money by virtue of its commercial activities. Indeed, in some instances the conditions in the interbank market diverged from what would be expected under a currency board regime. In this period, the currency board was a nonbank client of HSBC.

In July 1988, the interbank clearing system was brought under the control of the currency board. Under the Accounting Arrangements, the customer-banking relationship between the currency board and HSBC was reversed. While HSBC remained the clearing bank, its interbank activities were circumscribed so that its net clearing balance with the rest of the banking system was not larger than its own account with the currency board, effectively capping its ability to create liquidity. This had the effect of bringing the aggregate balance under the (indirect) control of the currency board.

In December 1996, a real time gross settlement system was introduced, and the migration of the aggregate balance to the monetary authority was completed. From that time onward, all licensed banks were required to operate clearing accounts with the currency board rather than $\mathrm{HSBC}$, meaning that the aggregate balance was put directly on to the balance sheet of the currency board.

As a result, the responsibility for operating the clearing system also migrated to the HKMA. An interesting issue was how to manage intraday and end day liquidity without violating the flow constraint of the currency board. This was accomplished through the use of the Liquidity Adjustment Facility, which provided funding at penal rates through discounting Exchange Fund bills and notes, which were in ample supply. Since the proceeds from the issuance of Exchange Fund paper had been switched into foreign reserves, the flow constraint of the currency board was respected.

In this period, the currency board lacked any commitment to convert any part of domestic currency to foreign currency. This applied to both the aggregate balance and to notes and coins in circulation. The currency board had discretion on when to trigger convertibility, and this usually took place in episodes of weak-side pressures. In contrast, there was in place a clear commitment to convert Certificates of Indebtedness (i.e., those certificates received by note issuing banks when turning over foreign exchange to the currency board) at the rate of 7.8 per U.S. dollar. Under more normal circumstances, the currency board stayed out of the foreign exchange market.

${ }^{1}$ In this period, the currency board was operated by the Office of the Exchange Fund. The Hong Kong Monetary Authority, which now operates the currency board, was established in 1993. 


\section{Box II.2. The 1998 Strengthening of Hong Kong SAR's Currency Board Arrangements}

In response to the effects of capital market turbulence during late 1997 and the first half of 1998, the HKMA introduced in September 1998 the following package of seven technical measures. The measures were designed to (i) demonstrate the government's commitment to the Linked Exchange Rate System, and (ii) dampen interest rate volatility, which in the view of the authorities had been excessive and potentially destabilizing.

1. The HKMA provided a clear undertaking to licensed banks to convert Hong Kong dollars in their clearing accounts into U.S. dollars at a fixed rate, the convertibility undertaking. The rate was initially 7.75 per U.S. dollar, but was moved gradually to 7.80 per U.S. dollar - where it has since remained. Of note, no stipulations were made for converting U.S. dollars into Hong Kong dollars for bank clearing accounts.

2. The bid rate of the Liquidity Adjustment Facility (LAF) was removed, as it had fallen into disuse since the establishment of the Real Time Gross Settlement system.

3. The LAF offer rate was renamed the base rate and its floor was stipulated as the greater of the US Federal Funds rate plus 150 basis points, or the five day moving average of the one month HIBOR. The LAF was renamed the Discount Window.

4. The HKMA liberalized the use of Exchange Fund paper as collateral at the discount window and removed the penal interest rate (see 6 . below for new borrowing terms).

5. The HKMA clarified that new Exchange Fund paper would only be issued when there is an inflow of funds, allowing the additional paper to be backed fully by foreign reserves.

6. In accessing the Discount Window, the discount rate was set at the base rate for the first 50 percent of Exchange Fund paper held by a bank, and the base rate plus the greater of the overnight HIBOR or 5 percent for the next 50 percent of paper.

7. Terms for discounting other eligible paper (notes issued by the Hong Kong Mortgage Corporation, Airport Authority and Mass Transit Railway Corporation) were set equal to Exchange Fund paper for AAA rated paper and plus 25 basis points for lower ratings.

In addition to the above measures, the HKMA also announced moves toward greater transparency and disclosure of currency board operations, including a page on Reuters.

Source: Hong Kong Monetary Authority (1998). 
Figure II.1: Hong Kong Dollar Spot and Forward Rates

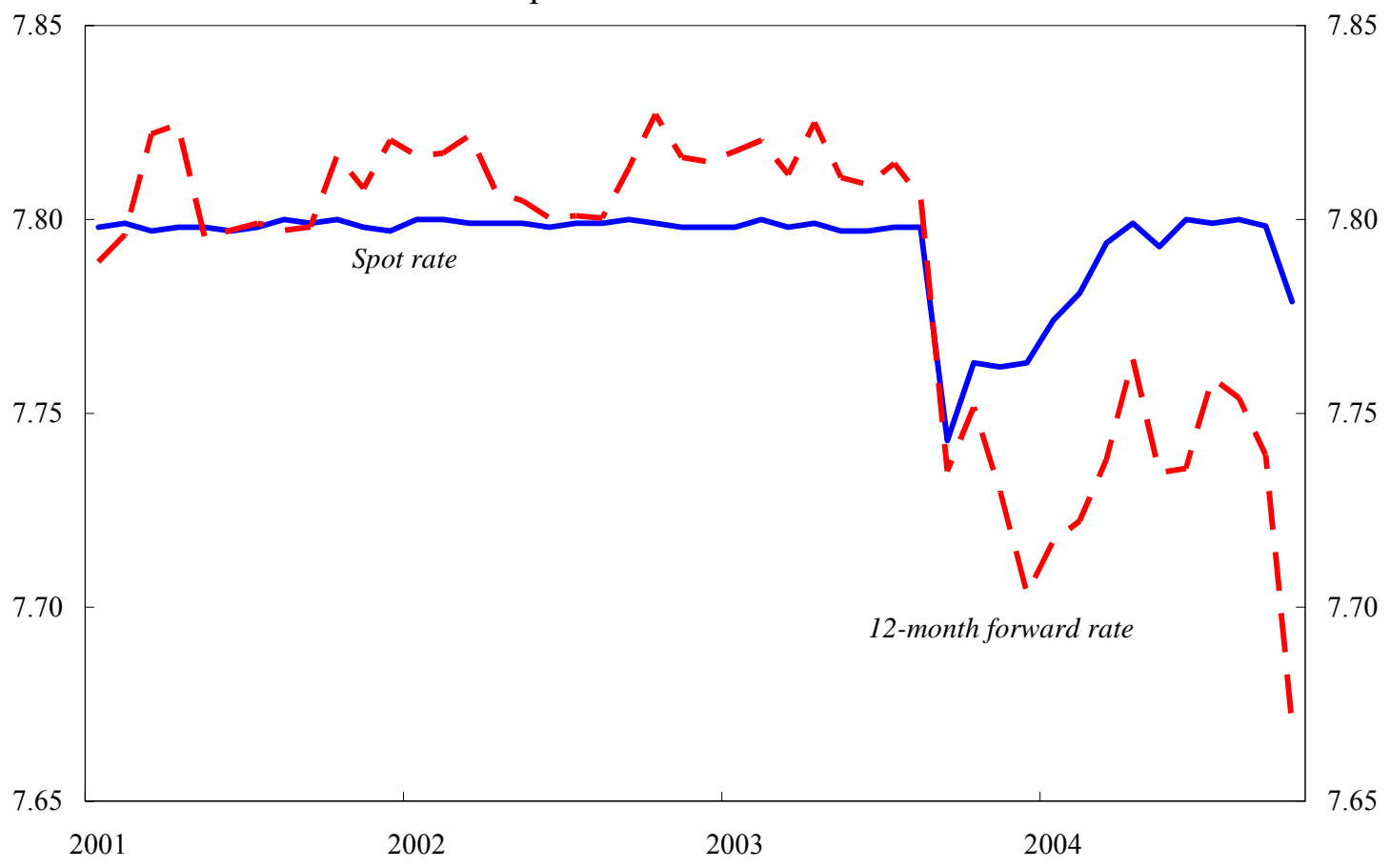

Figure II.2: Aggregate Balance

(In billions of Hong Kong dollars)

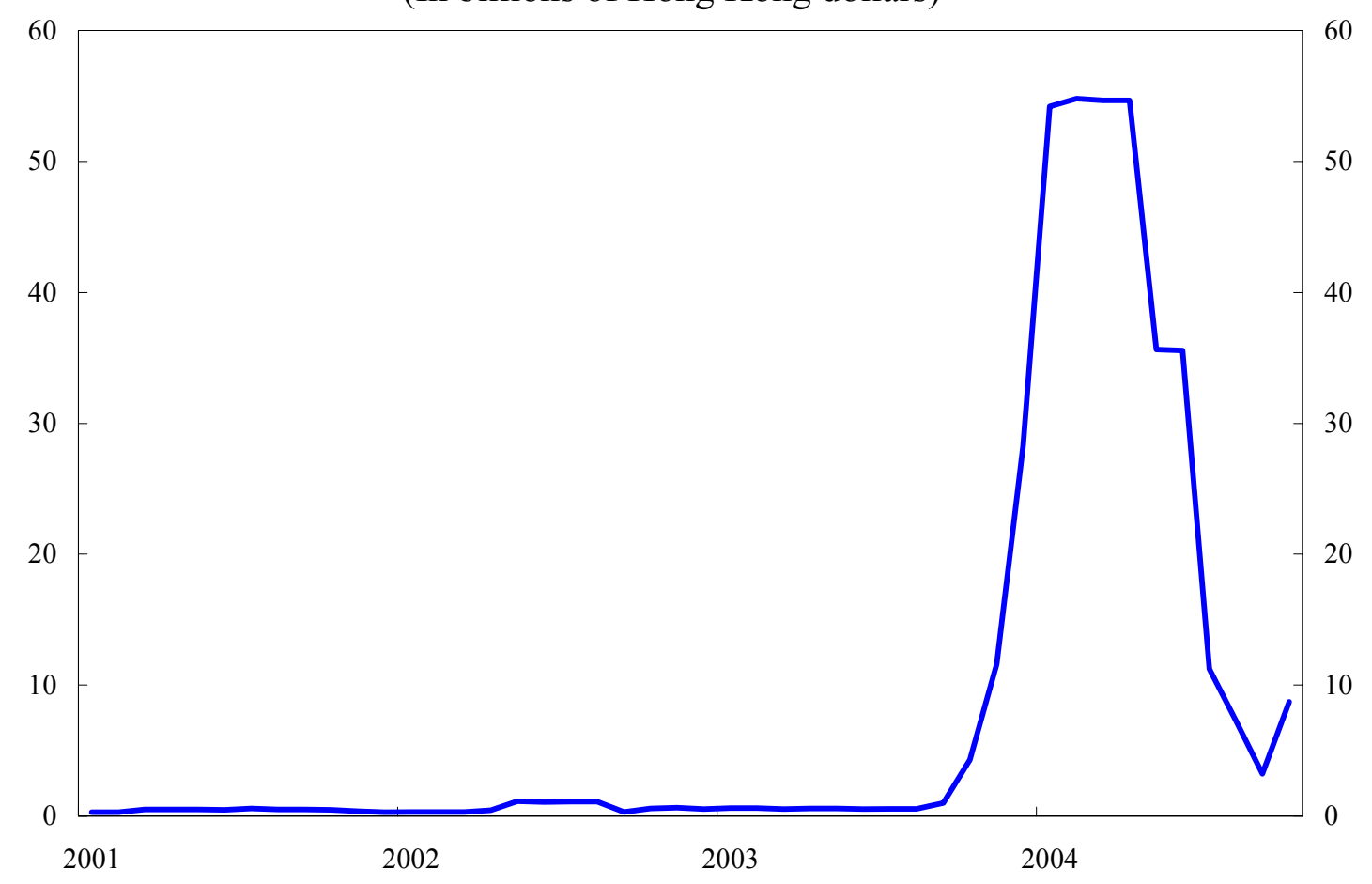


Figure II.3: Net Benefit Function

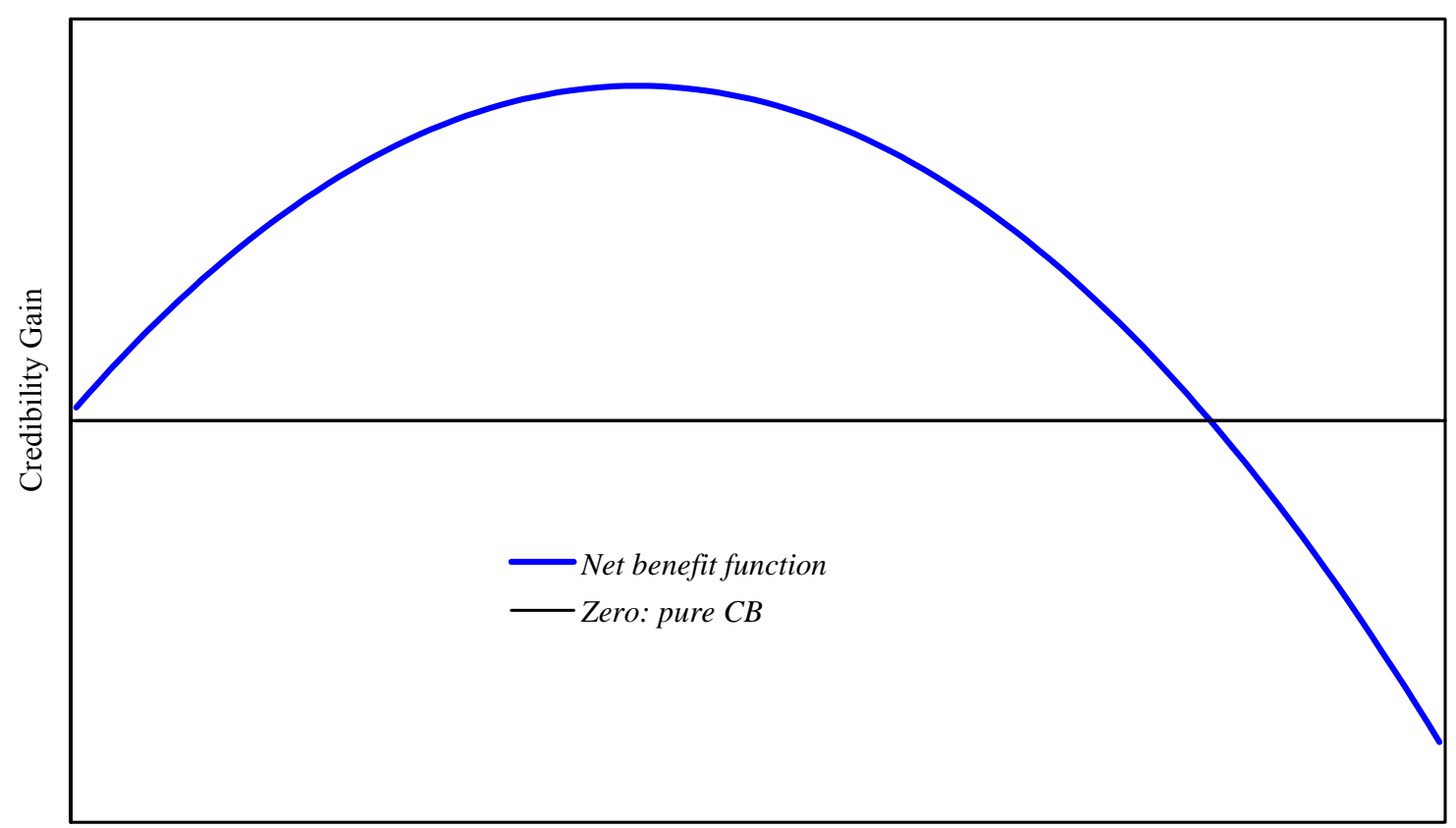

Potential Exchange Rate Shock

Figure II.4: Determination of the Optimal Strategy

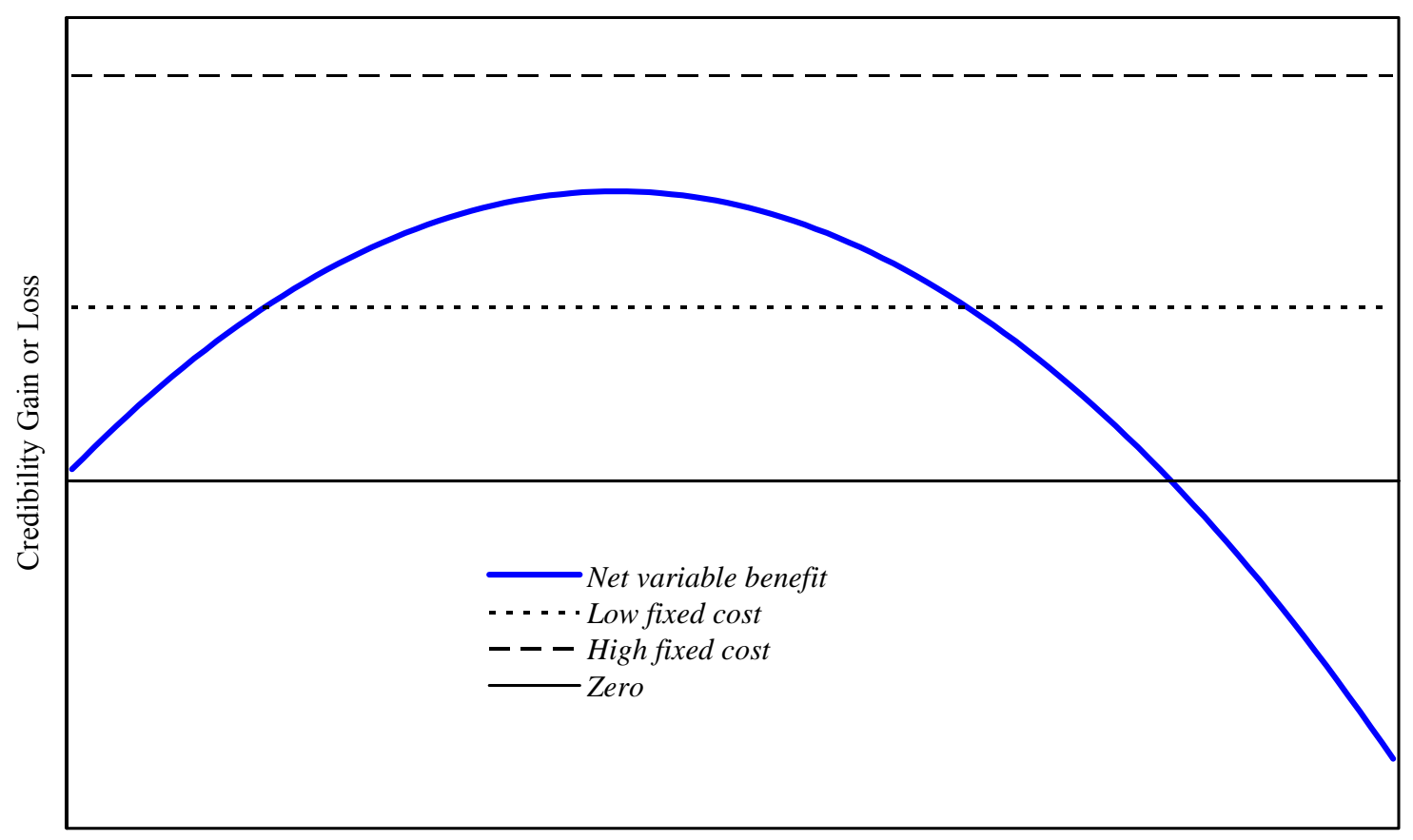

Potential Exchange Rate Shock 


\section{Procyclicality of Credit in the Banking System in Hong Kong SAR ${ }^{1}$}

\section{A. Introduction}

1. Credit growth is procyclical in most countries and can often amplify the economic cycle. Credit naturally tends to expand during upturns and contract during downturns but can fuel excessive investment during booms and deepen cyclical downturns when the financial system fails to adequately discipline lending. Asset prices and property prices, in particular, can play an important role in this process. Rising asset prices encourage more rapid credit growth by raising the value of the collateral against which credit is offered. Similarly, during a downturn, the decline in asset prices can exacerbate the decline in credit.

2. Some degree of procyclicality in credit is inherent in any economy, and can occur even in the absence of financial market imperfections. The returns on investment are often sensitive to macroeconomic conditions and a firm may choose to reduce investment during a recession even though it has access to a willing lender. Households may also choose to postpone purchases that they would finance with credit during downturns.

3. The banking systems can amplify the natural tendency towards a procyclical credit through a number of channels. For example:

- Capital requirements can cause banks to tighten credit following losses during a downturn in order to limit the decline in their capital ratios, which can deepen the recession.

- Agency problems can increase the role of collateral and borrower's prospective cash flows in lending decisions (Bernanke and Gertler, 1989), making credit more sensitive to changes in asset prices and borrowers' balance sheets. During cyclical downturns, for example, the decline in cash flow and collateral value can reduce the creditworthiness of some borrowers, leading to a contraction in credit. ${ }^{2}$

- Possible coordination problems can exacerbate procyclicality when the decision to reduce lending during a downturn is the prudent response for each individual bank but leads to a collectively inefficient outcome as the aggregate impact on credit can deepen the downturn.

4. Since some degree of procyclicality is normal, the policy challenge facing country authorities is to prevent the financial system from exacerbating it. This would limit the costs of high procyclicality, including the risk to financial stability from deeper

\footnotetext{
${ }^{1}$ Prepared by Marcos Chamon, ext. 35867 (APD) and Sean Craig, ext. 38714 (MFD).

2 This effect is stronger if banks tend to rely largely on collateral when allocating credit because their credit risk assessment capacity is weak.
} 
cyclical downturns, the lower quality of investment when credit is growing rapidly and the failure to finance profitable investment projects when credit is contracting. There may be little supervisors can do about information and agency problems. However, they can try to limit the extent to which the banking system amplifies procyclicality due to weak credit assessment and an excessive reliance on collateral. They could improve incentives to better measure and control credit risk over the cycle. Efforts to expand securitization and insurance of property loans could reduce the banks' risk exposure to the sector. More extreme measures include adjusting capital adequacy ratios over the cycle and provisioning guidelines to encourage portfolio diversification and dampen credit expansions and contractions.

\section{The correlation of credit growth with respect to growth in GDP and in property} prices tends to be higher on average in Hong Kong SAR than in comparable Asian economies. Craig et al. (2004) study procyclicality in East Asian financial systems. They provide a cross-country comparison of the correlations between growth in credit to the private sector and growth in GDP and in property prices. Table III.1 shows some of their findings. While stronger positive correlations suggest higher procyclicality, caution is needed when interpreting these correlations or comparing them across countries. ${ }^{3}$

\section{In Hong Kong SAR, the concentration of property lending in bank loan} portfolios could contribute to procyclicality. The link between collateral values and credit is stronger in property-related lending because property is the primary form of collateral and property prices tend to be highly sensitive to economy-wide shocks. ${ }^{4}$ Thus, a more concentrated exposure to property raises the vulnerability of the banking system to aggregate shocks that affect property prices, which can contribute to procyclicality in lending. These effects have been dampened, however, by the high level of liquidity in the banking system.

\section{The procyclicality of credit has not posed a threat to Hong Kong SAR due to its} well supervised and sound banking system. A major potential cost of high procyclicality is the risk to financial stability from deeper cyclical downturns. The very well capitalized and highly liquid banking system should be able to effectively weather such downturns, suggesting that this risk has been, and is likely to remain, very low. The resilience of Hong Kong SAR's banking system in the wake of the Asian crisis is particularly noteworthy, and facilitated the recovery from the crisis.

\footnotetext{
${ }^{3}$ Correlations indicate comovement but do not provide information on the amplitude of the cycle. In addition, correlations may change over time and they tend be higher during periods of high volatility. Also, structural factors such as financial liberalization may lead to a onetime increase in the level of credit that will affect its correlation with other variables, even though that one-time change is not due to cyclical factors. Nevertheless, correlation coefficients remain a useful first approximation to the extent of procyclicality.

${ }^{4}$ The correlation between quarterly year-on-year real changes in property prices and real GDP growth over the last ten years is over 0.6.
} 


\section{B. Features of Hong Kong SAR's Financial System Relevant to Procyclicality}

8. Hong Kong SAR has a large and well developed equity market, which should attenuate the effects of procyclical credit. The stock market in Hong Kong SAR is the largest in Asia after Japan. Its market capitalization currently stands at about HK\$5.5 trillion, which is roughly three times the size of outstanding bank loans. Equity financing can reduce procyclicality since it makes firms less vulnerable to cyclical changes in the supply of credit.

9. The bond market remains relatively small, with bank lending accounting for a large share of debt financing. The outstanding stock of Hong Kong dollar debt in 2003 (excluding that in the Exchange Fund) was HK $\$ 438$ billion, of which 32 percent is associated with Authorized Institutions (AIs). Local corporates account for only HK $\$ 33$ billion, which is less than 2 percent of total loans for use in Hong Kong SAR. An expansion of the bond market could potentially dampen procyclicality.

10. The share of property loans in bank lending has steadily increased, going from 39 percent in 1991 to 58 percent in 2003, even as banks became more liquid. Figure III.1 plots the evolution of loans measured in constant prices broken down by three different categories including two types of property loans - private residential loans and loans for property building, construction, development and investment - and other types of loans for use in Hong Kong SAR. ${ }^{5}$ Loans for use in Hong Kong SAR declined following the Asian financial crisis, but by 2000 they had resumed their growth path, albeit at a slower rate than prior to the crisis. However, property loans continued to expand throughout the period, increasing their share in total loans.

11. The increasing share of property loans in bank lending is largely attributable to weak credit demand by other sectors following the Asian crisis. The weak demand from other sectors, combined with the good performance of property loans despite the bursting of the property bubble, led to a continuing expansion of the latter. In fact, property-related loans appear to have been safer than other types of loans during this period (Gerlach et al., 2004). Specific features of the Hong Kong SAR property market help attenuate credit risk in this sector. For example, the practice of pre-selling units reduces the leverage of developers, the prudential limit on the loan to value ratio is relatively low, and the stigma of defaulting has prevented it even in cases where mortgages had negative equity. Finally, many home buyers have substantial net worth and so may be better able to avoid default when there are adverse shocks.

\section{Extent of Procyclicality of Bank Lending in Hong Kong SAR}

12. The growth rate of bank loans is positively correlated with the growth rate of GDP and with property prices. Quarterly data on bank loans are available broken down by

\footnotetext{
${ }^{5}$ The GDP deflator is used to convert current prices to constant prices. That index is more appropriate than the CPI for our purposes because of its broader coverage.
} 
sector beginning in 1981Q4. ${ }^{6}$ All series are converted to constant 2000 prices using the GDP deflator. All growth rates are based on year-on-year changes. Table III.2 presents correlation coefficients between growth in loans and growth in GDP and in property prices, as well as the elasticities implied by univariate regressions. The results indicate that:

- Growth in loans for use in Hong Kong SAR is strongly positively correlated with growth in GDP, and the estimated elasticity suggests a strong comovement (Figure III.2) that has strengthened over the last 10 years.

- The comovement of loans with equity prices is relatively weak.

- Growth in loans for use in Hong Kong SAR is correlated with changes in property prices and the correlation and the associated elasticity have increased substantially in the last ten years (Figure III.3). This increase in comovement may be due to the simultaneous large declines in property prices and loans following the Asian crisis

13. Craig et al. (2004) show that provisions expand when loans contract, contributing to procyclicality, and that credit comoves with the economic cycle in Hong Kong SAR. These authors use a panel of bank-level data from BankScope to estimate the determinants of loan growth, asset margin and actual provisioning rates. The estimated elasticity of loan growth with respect to GDP growth is about 1, while the estimated elasticity of the actual provisioning rate with respect to loan growth is about -2 .

\section{The larger role of the property sector in the lending portfolio of banks appears} to contribute to the procyclicality of credit. Property-related loans move with the property cycle, with the strength of this comovement being stronger for residential property prices than for commercial property prices (Table III.3). The role of property collateral values in property-related lending may help explain this comovement. Demand-side effects may also contribute (for example, higher property prices increase the size of the loan needed to finance a given property purchase). As bank lending becomes more concentrated in the property sector, the procyclicality of credit could increase because property prices are relatively volatile and procyclical, which leads to comparable movements in collateral values. These series are plotted in Figure III.4.

\section{Procyclicality in the property sector can also spill over into other sectors.}

Movements in property prices could contribute to the procyclicality of credit to other sectors where property is also used as collateral. In fact, the comovement of nonproperty-related loans with the property cycle is roughly the same as some types of property loans

\footnotetext{
${ }^{6}$ We focus on loans for use in Hong Kong SAR for two reasons. First, their cyclical properties are more relevant to Hong Kong SAR's economy than the ones of external loans. Second, much of the changes in external loans are driven by offshore booking practices of foreign banks, which do not affect credit supply or credit demand in Hong Kong SAR.
} 
(Table III.3). This suggests that such spillovers do occur and that property collateral may indeed play a significant role in nonproperty-related lending in Hong Kong SAR.

\section{Options for Policy Makers}

16. Banks do not internalize the effects of their actions on the rest of the economy so their actions may deviate from what is optimal from the perspective of policy makers. For example, reducing credit during a downturn may be an individually optimal prudential response for each bank but could lead to a collectively inefficient outcome by contributing to a credit crunch that exacerbates the downturn. As a result, policy makers may be more willing to accept lower credit growth during upturns in order to reduce the need for an adjustment during downturns relative to what would result from banks' lending decisions. One step in this direction would be for policy makers to ensure that property lending is indeed based on capacity to repay as well as collateral. This would reduce the potential for property price changes to exacerbate the cycle and reduce the risk of default in downturns. Bank supervisors in Hong Kong SAR have already taken steps to ensure that banks adequately take capacity to repay into account.

\section{There are some measures available to the Hong Kong SAR authorities to} dampen procyclicality. One option would be to expand the capacity to securitize and insure property-related risks. Supervisors could further encourage the securitization of property loans as a way to increase diversification and to transfer the risk to other institutions better able to bear it. This would also help to develop bond markets in Hong Kong SAR. At present, banks may prefer to maintain their exposure to the property sector given the weak demand by other sectors. Banks are holding a large amount of liquidity. The loans to deposits ratio (denominated in Hong Kong Dollars) is currently about 85 percent, which is a historical low and significantly below its pre-crisis level (Figure III.5). This liquidity can dampen procyclicality. However, if credit demand by the nonproperty sector picks up and banks reduce their liquidity, there will be more scope for the financial system to exacerbate the procyclicality of credit.

\section{Policy makers could also encourage banks to adjust their capital ratio and} provisioning over the cycle to help reduce procyclicality. This would lead banks to hold more capital against risks during cyclical upswings, which would tend to slow loan growth. It would also provide more room for bank capital to decline in downturns, which would dampen procyclicality. Banks may make provisions based on short-term measures of risk for longer-term credits. This could cause them to raise provisions during downturns and lower them during expansions. ${ }^{7}$ Options for provisioning guidelines include:

\footnotetext{
${ }^{7}$ Gerlach et al. (2004) show that provisions track non-performing loans very closely in Hong Kong SAR. Craig et al. (2004) show that provisions expand when credit contracts and viceversa.
} 
- Bank provisioning based on long-term average loss rates, effectively extending ex-ante general provisioning to take into account risks arising from procyclicality. Such a system, similar to the "statistical provisioning" introduced in Spain in 2000, would tend to slow lending growth during booms since provisions will reflect long-term average risks, not the lower short-term risks. It would also attenuate the decline in lending during downturns, since smaller increases in provisions would be needed when risks materialize. However, such an approach faces a number of technical challenges, such as ensuring conformity with International Accounting Standard (IAS) 39.

- Requiring higher provisions for loans in sectors where the banking system as a whole concentrates lending (i.e., the property sector). This would encourage diversification away from those sectors.

19. At present, the procyclicality of credit does not seem to be a significant problem for Hong Kong SAR's economy. It is possible that much of the observed procyclicality is driven by demand and structural issues. However, if the future of the procyclicality of credit becomes a concern, the authorities would have several options available to respond. 


\section{References}

Bernanke, Ben, and Mark Gertler, 1999, "Agency Costs, Net Worth, and Business Fluctuations," American Economic Review, Vol. 79, pp.14-31.

Borio, Claudio, Craig Furfine, and Phillip Lowe, 2001, "Procyclicality of the Financial System and Financial Stability: Issues and Policy Options," BIS Papers No. 1, BIS background paper.

Craig, Sean, E. Phillip Davis, and Antonio Garcia, 2004, "Sources of Pro-Cyclicality in East Asian Financial Systems," Draft Working Paper, IMF.

Gerlach, Stefan, Wensheng Peng, and Chang Shu, 2004, "Macroeconomic Conditions and Banking Performance in Hong Kong: A Panel Data Study," Hong Kong Monetary Authority Research Memorandum. 
Table III.1: Correlation Coefficients with Year-on-Year Growth in Real Credit 1/

\begin{tabular}{lcc}
\hline & $\begin{array}{c}\text { Year-on-Year Growth in Real } \\
\text { GDP }\end{array}$ & $\begin{array}{c}\text { Year-on-Year Growth in Real } \\
\text { House Prices }\end{array}$ \\
\hline Hong Kong SAR & 0.44 & 0.66 \\
Australia & 0.50 & 0.34 \\
Mainland China & -0.15 & n.a. \\
Japan & 0.65 & 0.85 \\
Korea & 0.35 & 0.35 \\
Malaysia & 0.49 & 0.71 \\
New Zealand & 0.03 & 0.10 \\
Philippines & 0.43 & n.a. \\
Singapore & 0.35 & 0.42 \\
Thailand & 0.35 & -0.23 \\
& & \\
Average & 0.33 & 0.39 \\
\hline
\end{tabular}

1/ Figures based on quarterly data from 1984 to the present available through CEIC.

Table III.2: Correlation Coefficients and Elasticity of Growth in Loans for Use in Hong Kong SAR with Respect to: 1/

\begin{tabular}{lcccc}
\hline & 1981Q4-2004Q1 & 1994Q2-2004Q1 \\
\hline Real Growth in: & Correlation & Elasticity & Correlation & Elasticity \\
\hline GDP & 0.22 & $0.37 *$ & 0.35 & $0.52 *$ \\
Hang Seng index & -0.23 & $-0.06 *$ & -0.03 & -0.01 \\
Residential property prices & 0.22 & $0.10 *$ & 0.61 & $0.22 *$ \\
Office property prices & 0.32 & $0.10 *$ & 0.31 & 0.10 \\
\hline
\end{tabular}

1/ Elasticities based on a univariate regression of year-on-year real growth in the corresponding variable on the real growth in loans. The symbol * indicates a statistically significant coefficient at the 5 percent level. 
Table III.3: Correlation Coefficients and Elasticity of Growth in Loans with Respect to Growth in Property Prices in the Last Ten Years (1994Q2-2004Q1) 1/

\section{Real Growth in Residential Real Growth in Office Property Prices Property Prices}

\begin{tabular}{lcccc}
\hline Real Growth in & Correlation & Elasticity & $\begin{array}{c}\text { Correlatio } \\
\mathrm{n}\end{array}$ & Elasticity \\
\hline $\begin{array}{l}\text { Private residential loans } \\
\text { Loans for property building, } \\
\text { const., dev. and inv. }\end{array}$ & 0.31 & 0.10 & -0.18 & -0.05 \\
$\begin{array}{l}\text { Nonproperty loans for use in } \\
\text { Hong Kong SAR }\end{array}$ & 0.50 & $0.31 *$ & 0.30 & 0.16 \\
& 0.62 & $0.26 *$ & 0.45 & $0.16 *$ \\
\hline
\end{tabular}

1/ Elasticities based on a univariate regression of year-on-year real growth in the corresponding property variable on loan variable. The symbol * indicates a statistically significant coefficient at the 5 percent level. 
Figure III.1: Total Loans by Type of Use (2000 Constant Prices) (In billions of Hong Kong Dollars)

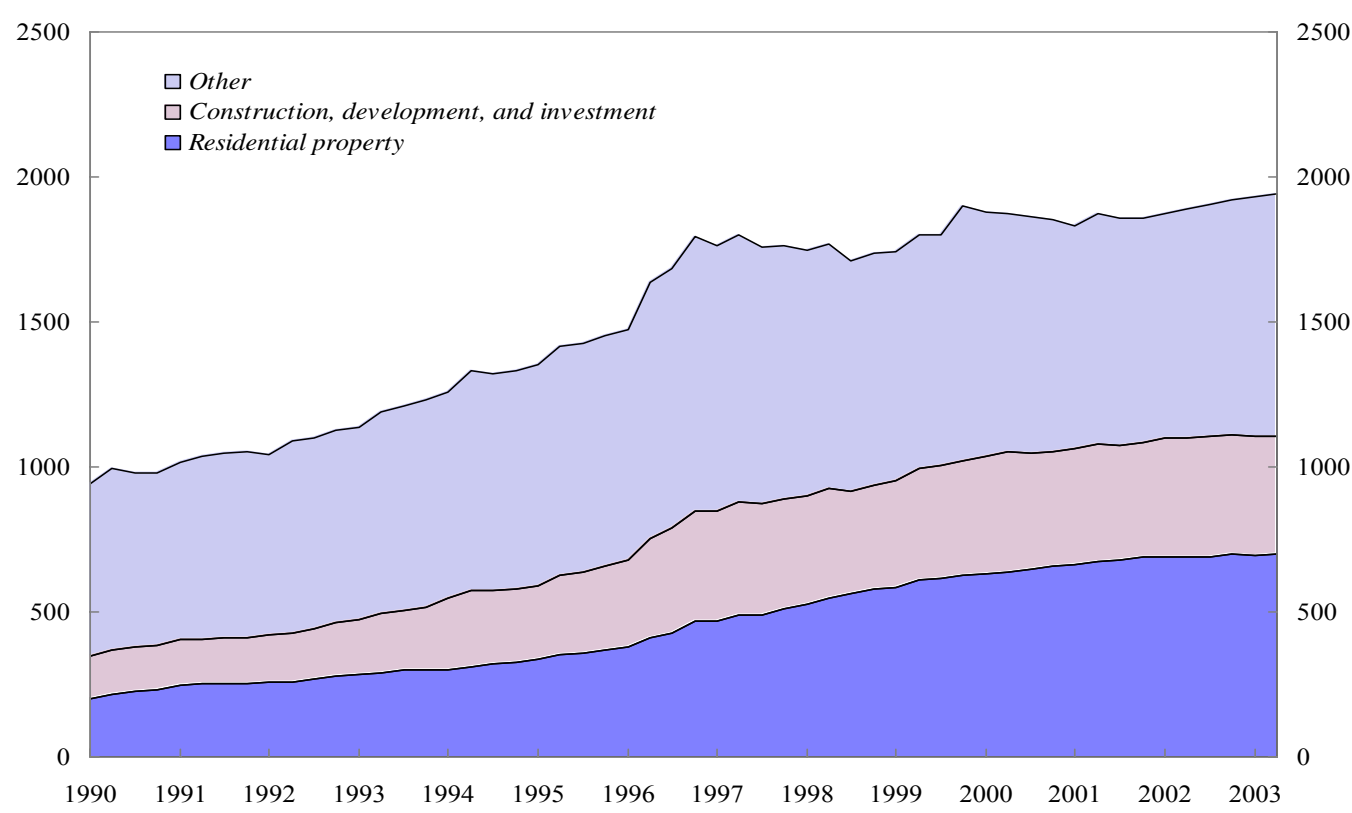

Source: CEIC.

Figure III.2: Real Growth of GDP and of Loans for Use in Hong Kong SAR (Year-on-year percentage change)

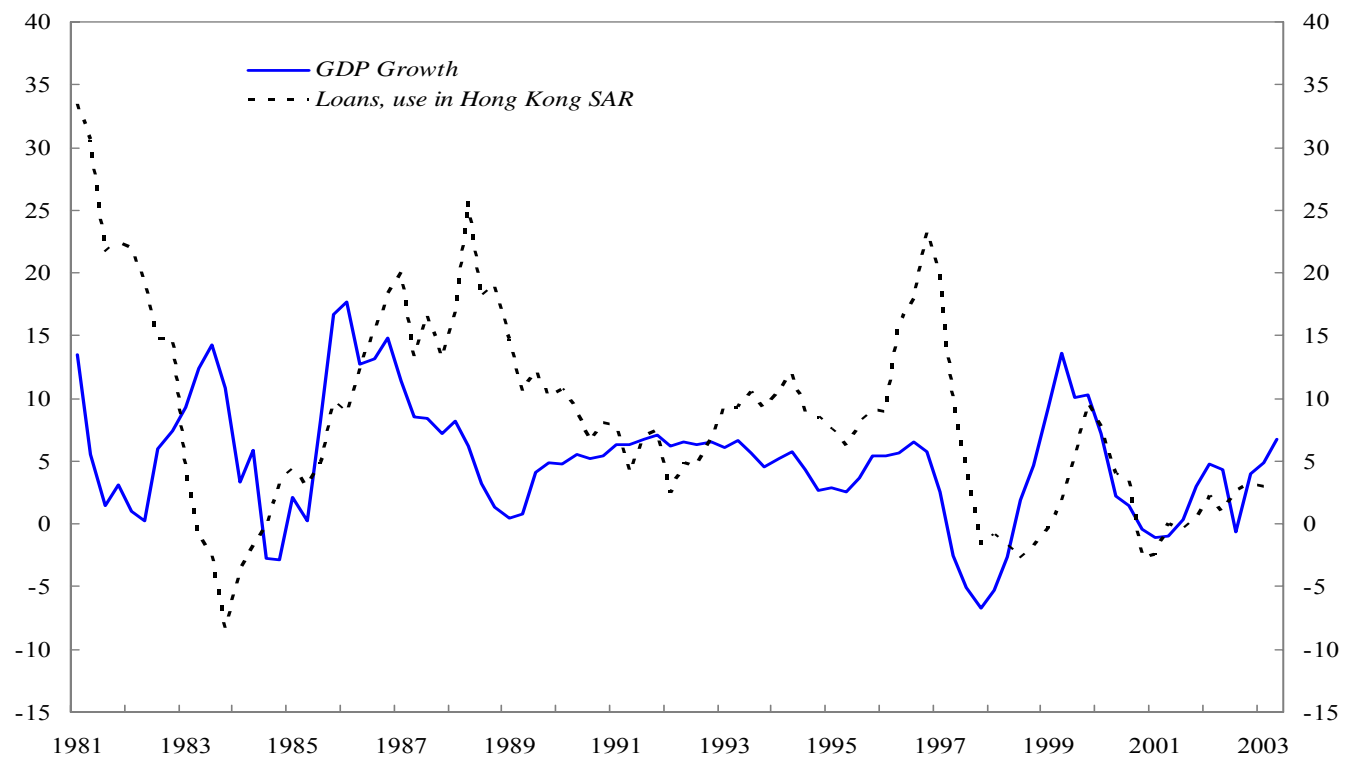

Source: CEIC. 
Figure III.3: Real Growth of Loans for Use in Hong Kong SAR and of Property Prices (Year-on-year percentage change)

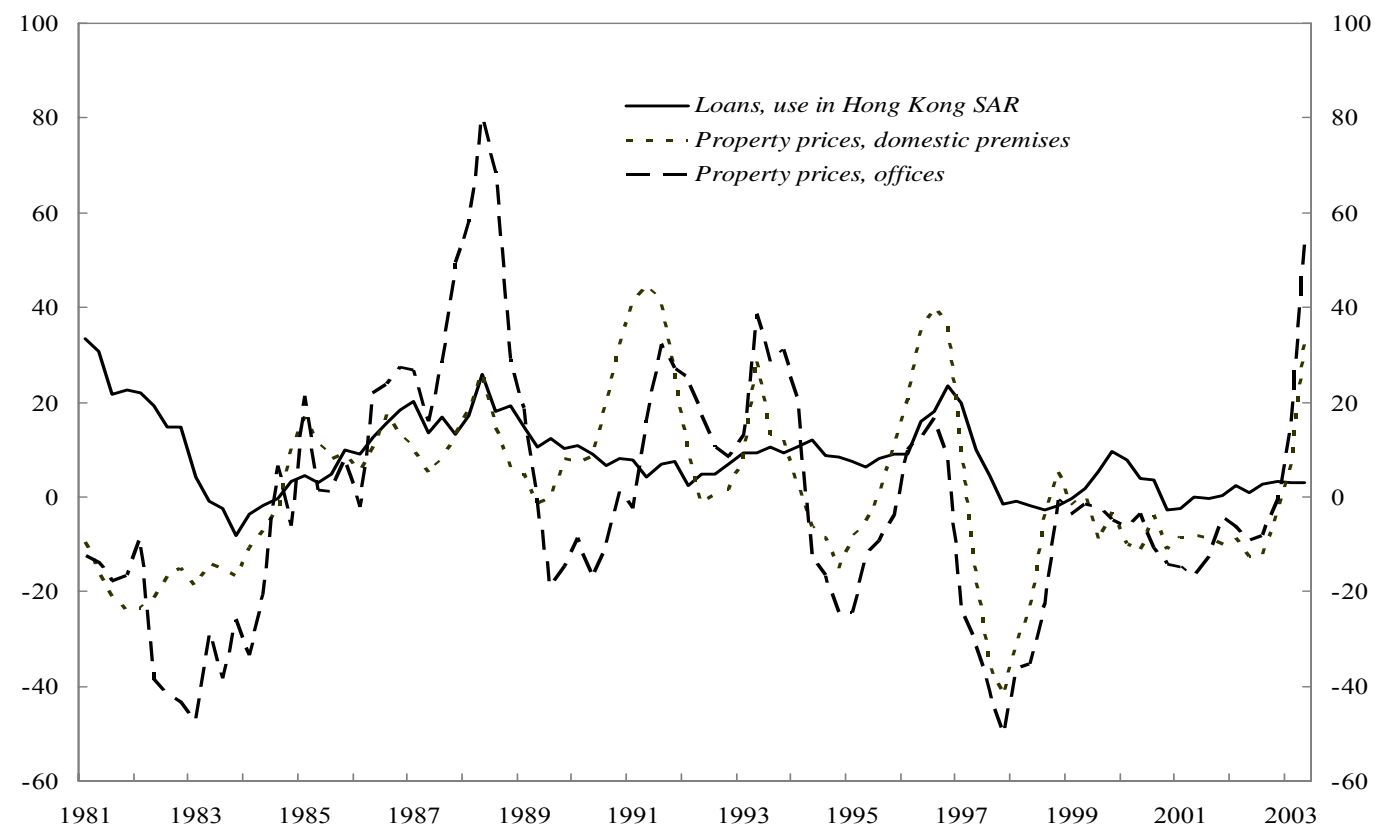

Source: CEIC.

Figure III.4: Real Growth of Property and Nonproperty Loans for Use in Hong Kong SAR and of Property Prices

(Year-on-year percent change)

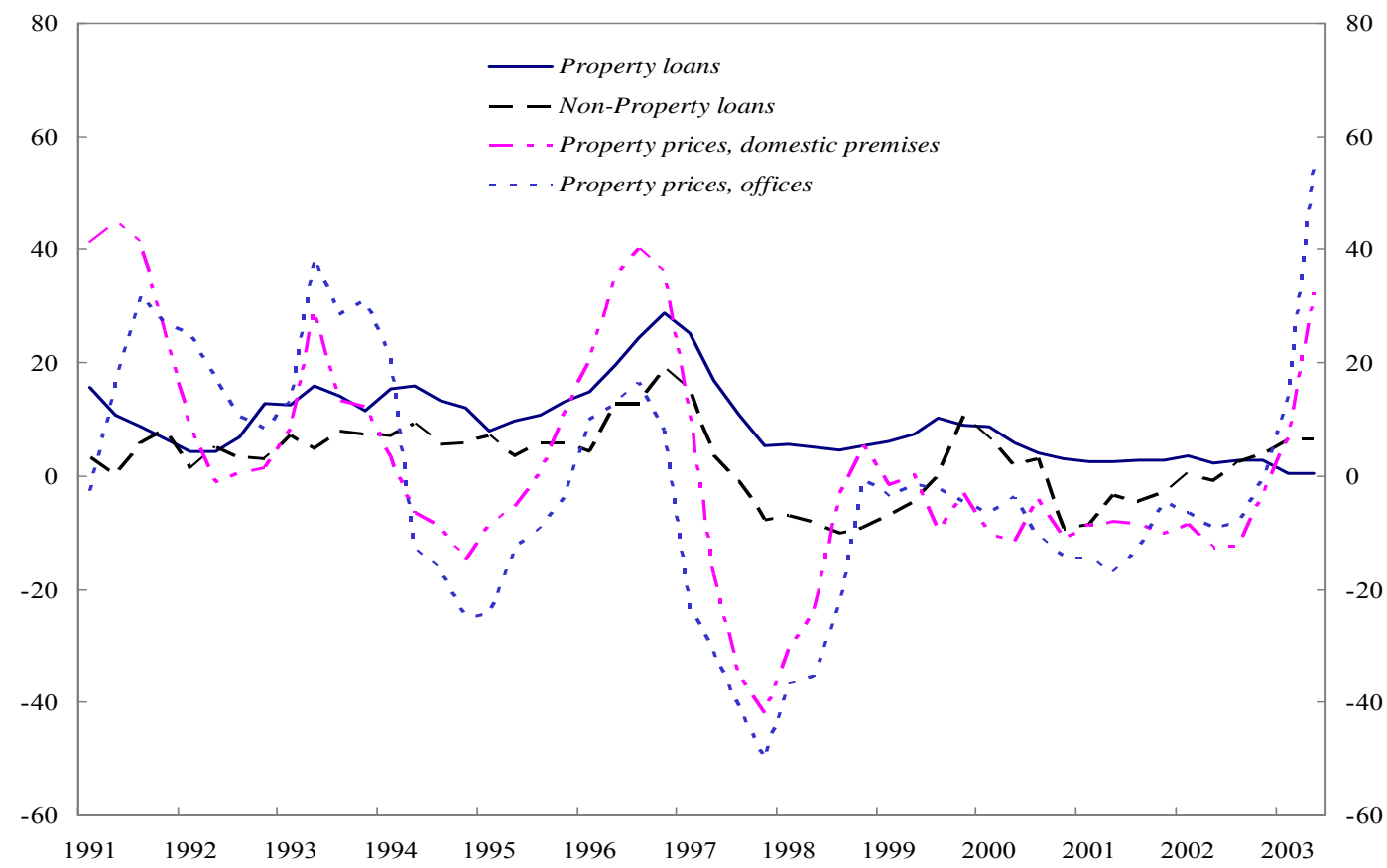

Source: CEIC. 
Figure III.5: Ratio of Hong Kong Dollar Loans to Deposits

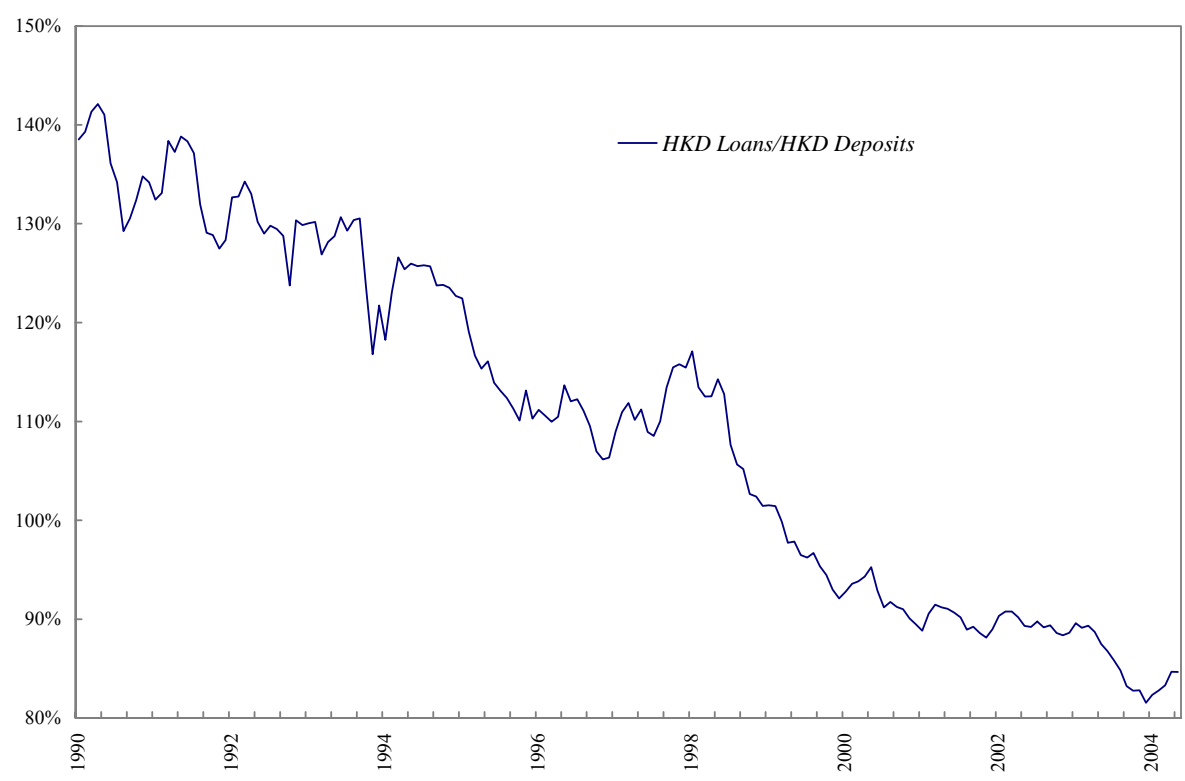

Source: CEIC. 


\section{RECENT LABor MARKET DEVELOPMENTS IN HONG KONg SAR ${ }^{1}$}

\section{A. Introduction}

1. Hong Kong SAR's labor market performed well for the two decades following the onset of reforms on the Mainland in the late-1970s. Hong Kong SAR's investments in the Mainland - mainly in the Pearl River Delta (PRD) region-generated substantial crossborder flows in goods and, to a lesser extent, services, creating considerable employment opportunities. On average, the unemployment rate remained at around $2 \frac{1}{2}$ percent between 1981 and 1997.

2. By contrast, in the post-Asian crisis period, labor market outcomes deteriorated markedly. The unemployment rate rose substantially and peaked at 8.6 percent in mid-2003 in the aftermath of the outbreak of Severe Acute Respiratory Syndrome. While the unemployment rate had dropped by 2 percentage points to 6.5 percent by December 2004 and is projected to fall below 6 percent by end-2005 reflecting the strong economic rebound, it remained considerably higher than the pre-1997 levels. Structural unemployment appears to have increased, reflecting skills mismatches stemming from globalization and closer integration with the Mainland, which has reduced the relative demand for unskilled labor.

3. In recent years, the government has taken a number of measures to address the skills mismatch problem and improve labor market performance. The measures include increasing the number of professionals through admission schemes of talents and professionals in the short run and education reforms in the long run, which should, in turn, increase demand for local services that will absorb low-skilled workers.

4. This paper reviews recent labor market developments and the government's policy response. Section $B$ outlines the major effects of rising integration with the Mainland on Hong Kong SAR's labor market. Section C describes the measures taken by the government to address these challenges. Section D concludes.

\section{B. Rising Integration with the Mainland and Hong Kong SAR's Labor Market}

5. High operating costs in Hong Kong SAR led to the outsourcing of low valueadded manufacturing activities to the PRD from the late 1970s onwards. When the Mainland authorities began their reform program in 1978, Hong Kong SAR already had the highest operating costs among the "four dragons." Apart from an abundant supply of land and labor, geographical proximity made the PRD a natural location for Hong Kong SAR to

\footnotetext{
${ }^{1}$ Prepared by Ida Liu Kit-ying of the IMF Resident Representative Sub Office in Hong Kong SAR.

${ }^{2}$ The "four dragons" are Hong Kong SAR, Korea, Singapore, and Taiwan.
} 
outsource its low value-added activities. ${ }^{3}$ Between 1978 and the mid-1990s, the relocation of factories to the PRD caused more than 500,000 factory jobs to move across the border. As a consequence, the share of manufacturing employment in total employment in Hong Kong SAR dropped from 38 percent in 1982 to 11 percent in 1996.

\section{As a result of this outsourcing, demand for Hong Kong SAR's services} blossomed. The large industrial base in the PRD created by Hong Kong SAR investment generated a jump in demand for Hong Kong SAR-based services since the Mainland's service sector was at that time underdeveloped. By transforming itself into the main service hub for Mainland China, many new jobs were created in Hong Kong SAR's tertiary sector, and a low average unemployment rate of $2 \frac{1}{2}$ percent was maintained despite the severe job loss in the manufacturing sector during the period.

7. From the mid-1990s onwards, service sector jobs began to migrate as well, as Hong Kong SAR lost its service supply monopoly to the Mainland. Given that the bulk of manufacturing operations had already been relocated, only around 150,000 manufacturing jobs were lost between 1996 and 2003. However, as Mainland China moved up the valueadded chain, relatively low-skilled service sector jobs began to move across the border as well. A notable case is the diversion of Guangdong province's trade and international cargo from Hong Kong SAR ports to ports in Shenzhen, which rose to prominence in the 1990s, again with the help of Hong Kong SAR-based investment. The share of Mainland exports that pass through Hong Kong SAR jumped from 5 percent in 1979 to a peak of 66 percent in 1993, but declined thereafter to 28 percent in 2003. Employment in Hong Kong SAR's import/export trades peaked at about 18 percent of total employment in 1996, and declined to 16 percent in $2003 .{ }^{4}$ Hong Kong SAR still retains a comparative advantage in high valueadded services such as in the financial sector.

\section{There has been a marked increase in structural unemployment since the}

mid-1990s. Specifically, the structural unemployment rate is estimated to have risen from 2 to 3 percent in the late 1980 s to $3 \frac{1}{2}$ to 5 percent in recent years. ${ }^{5}$ As the quality of human capital in the Hong Kong SAR economy did not keep pace with the need of economic restructuring, a skills mismatch resulted. This is evidenced on one hand by the much higher

\footnotetext{
${ }^{3}$ Firm ownership and control remained with Hong Kong SAR residents, meaning that the impact on GDP stemming from this outsourcing was much greater than on GNP.

${ }^{4}$ There is considerable anecdotal evidence of migration of low-end services jobs in other sectors to the Mainland. For example, the number of persons engaged in the radio paging services sector dropped from the peak of nearly 9,000 in 1995 to less than 300 in 2004 is due in part to the relocation of radio paging companies to Shenzhen and Guangzhou.

${ }^{5}$ The HKMA estimates the structural unemployment rate at $3 \frac{1}{2}$ to $4 \frac{1}{2}$ percent while the Hong Kong University of Science and Technology puts it at around 5 percent. In the services sector, which employs 85 percent of the labor force, the HKMA estimates that the structural unemployment rate has risen from 1/2 percent to 23/4 percent between 1982 and 2003.
} 
unemployment rate in the lower-skilled segments of the labor market and amongst workers that have lower educational attainment (Figures IV.1 and IV.2), and on the other hand by an increase in wage disparity and a rise in the return to education (Iakova, 2001).

9. The inflow of low-skilled arrivals from the Mainland has aggravated the skills mismatch problem. ${ }^{6}$ One aspect of closer integration with the Mainland is exemplified by the immigrants from the Mainland through the One-Way Permit Scheme. ${ }^{7}$ The 2001 Population Census data showed that, among new arrivals from the Mainland aged 15 and above, only 30 percent had upper secondary education or higher, compared with 52 percent for the same age group in Hong Kong SAR. From 1999 to 2001, it was estimated that these immigrants contributed to some 30 percent of the annual growth of the labor force. The task of training and upgrading the skills of adult new arrivals to meet the demand of the local economy poses a serious challenge for Hong Kong SAR.

\section{Measures to Address Hong Kong SAR’s Labor Market Challenges}

10. Looking ahead, employment challenges created by rising integration between Hong Kong SAR and the Mainland are formidable. According to the Hong Kong SAR Government's latest projections of manpower requirement and supply, there will be a surplus of 230,000 low-skilled workers and a shortfall of 100,000 highly skilled workers by 2007 (Box IV.1).

11. To improve the functioning of the lower-skilled end of the labor market, the government has undertaken the following initiatives, which are aimed at both the supply and demand sides:

- Providing retraining to disadvantaged workers who are displaced or unemployed. The Employees Retraining Board (ERB) was set up in 1992 to provide retraining to assist low-skilled displaced or unemployed workers in adjusting to changes in the economic environment. By end-December 2004, the ERB had provided retraining to 824,000 persons. About 70 percent of the retrained workers have been able to secure employment.

- Undertaking infrastructure projects. Most notably, the Government is working closely with the authorities in Macau SAR and Guangdong province on the Hong Kong SARZhuhai-Macau SAR Bridge project. The project will not only facilitate physical linkages amongst the three destinations, but is expected to create considerable employment opportunities for unskilled labor as well.

\footnotetext{
6 "New arrivals" are defined as immigrants who have resided in Hong Kong SAR for less than seven years.

${ }^{7}$ The scheme is devised primarily to facilitate family reunion. Indeed, many new families are created every year through intermarriage between Hong Kong SAR permanent residents and Mainland residents.
} 
- Identifying tourism as a core economic sector. The Government has identified tourism as one of the core economic sectors that Hong Kong SAR will focus on to maintain growth. ${ }^{8}$ The further development of this sector will increase the demand for relatively lowerskilled workers.

\section{In addition, the government has taken the following steps to address the shortage of high-skilled labor:}

- Doubling the proportion of senior secondary school leavers to receive tertiary education within 10 years. ${ }^{9}$ This will be achieved through education reforms. Since October 2000 , the Government has implemented a comprehensive education reform package with a view to better equipping future generations to cope with the advent of a knowledge-based economy. The reform covers a wide range of initiatives, including the curriculum, teaching practices, admission systems and assessment mechanisms.

- Promoting skills upgrading and continuing education among the existing workforce. In order to help upgrade the skills of in-service workers with secondary or lower education, the government launched the HK\$400 million "Skills Upgrading Scheme" in September 2001. Courses are developed through close collaboration between employers, employees, training providers and government officials. The scheme now covers 20 industries. A HK\$5 billion Continuing Education Fund was also launched in June 2002 to subsidize the enrolment of adults in continuing education courses. ${ }^{10}$

- Importing talented people and professionals. The Hong Kong SAR Government operates various admission schemes for skilled personnel from overseas and the Mainland. For the admission of foreign professionals, there are no quotas or job sector restrictions and, from 1997 to 2003, an average of about 16,600 foreign professionals have come to work in Hong Kong SAR each year. Similar schemes have been set up for admitting Mainland professionals as well but, due to restrictions, only about 600 applications were approved between December 1999 and July 2003. ${ }^{11}$ These restrictions were relaxed in mid-2003 and, as a result, the number of professionals from the Mainland admitted to Hong Kong

\footnotetext{
${ }^{8}$ The other sectors include financial services, producer services, and logistics.

${ }^{9}$ The government expanded basic education opportunities in the late 1970's by providing free and universal education, but only up to the level of junior secondary school. By 2003, only about 27 percent of the population of aged 15 and above have attained post-senior secondary qualifications.

${ }^{10}$ The specific sectors include logistics, financial services, business services, tourism, language, design and interpersonal and intrapersonal skills for the workplace.

${ }^{11}$ Restrictions include not allowing successful applicants under the Admission of Mainland Professional Scheme to bring in their dependants, and limiting the scheme to applicants in the information technology and the financial services sectors.
} 
SAR jumped sharply to 4,564 by October 2004 . The academic research and education sector absorbs 68 percent of these immigrants.

13. Increasing the supply of highly-skilled workers is likely to have positive spillover effects on the demand for low-skilled workers. There are considerable economic benefits in terms of consumption and creation of jobs, which skilled personnel could bring to Hong Kong SAR. For example, a Hong Kong SAR Government survey showed that, on average, 2.7 new jobs were created by the importation of each talent through the Admission of Talents Scheme during 2000 and 2001. Furthermore, a larger professional sector will increase demand for other personal services.

14. Broader initiatives such as the Closer Economic Partnership Arrangement (CEPA) and Pan-Pearl River Delta Cooperation Initiative are also likely to improve labor market outcomes in Hong Kong SAR. ${ }^{12}$ Indeed, the Individual Visit Scheme implemented in August 2003 under CEPA has already benefited the tourism industry tremendously: the unemployment rate in wholesale and retail, restaurants and hotels, and transport, dropped from a peak of 10.5 percent, 15.7 percent, and 7.7 percent respectively in mid-2003 to 6.9 percent, 9.5 percent and 4.3 percent respectively within one year.

\section{Conclusions}

15. As integration with the Mainland deepens, pressures to outsource lower valueadded activities are likely to continue. This, combined with the government's desire to transform Hong Kong SAR into a knowledge-based economy, implies that the demand for professionals and other skilled workers will remain relatively high, and that the skills mismatch problem is likely to persist.

16. The policy challenge is to facilitate the necessary labor market adjustment while minimizing distortions. The policy measures taken to date by the government underscore the view that the "market leads and the government facilitates." That said, it will be important to maintain a well-targeted and efficient social safety net that protects the most vulnerable members of society, who are most likely to feel the negative effects of integration with the Mainland.

${ }^{12}$ See Chapter I for a detailed analysis of these initiatives. 


\section{References}

Fan, Kelvin, 2004, “Sources of Unemployment,” Hong Kong Monetary Authority Quarterly Bulletin, June.

Hong Kong SAR Government, 2002, "Report on the Task Force of Population Policy".

Hong Kong SAR Government, 2003, "Report on 2002 Establishment Survey on Manpower Training and Job Skills Requirements."

Hong Kong SAR Government, 2003, "Report on Manpower Projection to 2007”, June.

Iakova, Dora, 2004, “Trends in Wage Inequality, 1981-2001”, IMF Occasional Paper 226 Hong Kong SAR: Meeting the Challenges of Integration with the Mainland.

Kwan, Vincent, 2004, “Employment Challenges," Hang Seng Economic Monthly, Hang Seng Bank, March.

Kwan, Vincent, 2001, "Processing Relocation: From Manufacturing to Services," Hang Seng Economic Monthly, Hang Seng Bank, October.

Lui, Francis T., and William W. Chow, 2004, “Economic Outlook 2004,” Hong Kong's Economic Forecast, Center for Economic Development, Hong Kong University of Science and Technology, January.

Sung, Yun-Wing, 2004, "Hong Kong's Economic Integration with the Pearl River Delta: Quantifying the Benefits and Costs," study commissioned by the Central Policy Unit of the Hong Kong SAR government, February.

Yam, Denise, 2004, "Pan-Pearl River Delta: From Diversity to Cooperation," Greater China Economics, Morgan Stanley, September. 
The Hong Kong SAR Government has undertaken periodic reviews and updates of its manpower requirements since 1999. The latest manpower projection (through 2007) was carried out in 2002.

The projections show that manpower requirements will increasingly favor the higher-skilled, better-educated and more experienced workers. The finance, insurance, real estate and business services sectors are expected to have the fastest increase in manpower requirements. In contrast, the manpower requirement for the local manufacturing sector is projected to continue to shrink. The manpower requirements for managers and professionals are projected to grow moderately, compared to a decline projected for workers below these levels (e.g. clerks, plant and machine operators and assemblers, etc,). Manpower requirements for persons at post-secondary level and at first degree level and above are projected to grow strongly. At the same time, manpower requirements for persons at lower secondary level and below and at upper secondary level is projected to decline.

In addition, the educational attainment requirement within different occupational categories is expected to be upgraded across-the-board. For example, there will be increase in demand for managers and administrators who have attained first degree level and above, and workers in elementary occupations (e.g. messengers, watchmen, etc) to have attained upper secondary level.

The projections of manpower requirements and supply suggest that in 2007, there will be a surplus in manpower at low education levels but a distinct shortfall in manpower at high education level. In other words, skill mismatch will be the major challenge facing the labor market in the coming future.

Projected manpower resource balance by broad educational attainment in 2007

Broad educational attainment
Lower secondary and below
Upper secondary
Post-secondary

First degree and above ${ }^{5}$ (a)

(b)

Projected
manpower
supply ${ }^{1}$
$1,236,200$
989,100
501,200
626,000

(c) $=$ (a) - (b)

$$
\begin{aligned}
& \text { Projected } \\
& \text { manpower } \\
& \text { resource } \\
& \text { balance } \\
& 133,500 \\
& 98,000 \\
& -65,200 \\
& -36,500
\end{aligned}
$$

$$
\text { (d) }=(\mathbf{c}) /(\mathbf{a}) \mathbf{x}
$$

$100 \%$

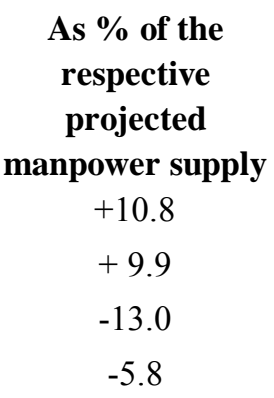

${ }^{1}$ Excluding foreign domestic helpers and imported workers.

${ }^{2}$ Including all employed Hong Kong SAR residents, regardless of their place of work, and excluding foreign domestic helpers.

${ }^{3}$ Including the upper secondary and craft levels.

${ }^{4}$ Including the matriculation, technician and sub-degree levels.

${ }^{5}$ Including the first degree and postgraduate levels.

+ Surplus in manpower supply against requirement.

- Shortfall in manpower supply against requirement. 
Figure IV.1: Unemployment Rate by Occupation Category

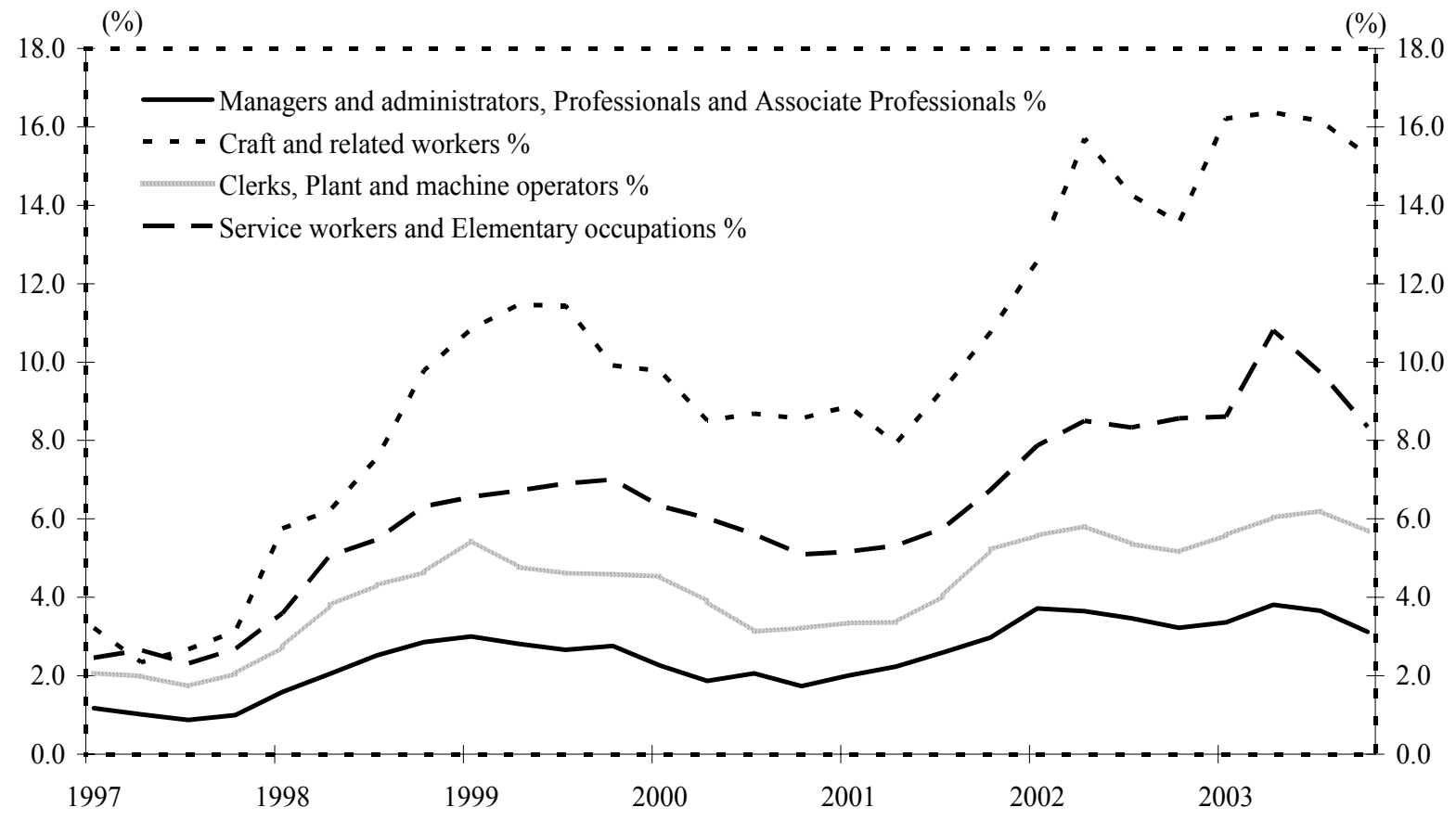

Figure IV. 2: Unemployment Rate by Educational Attainment

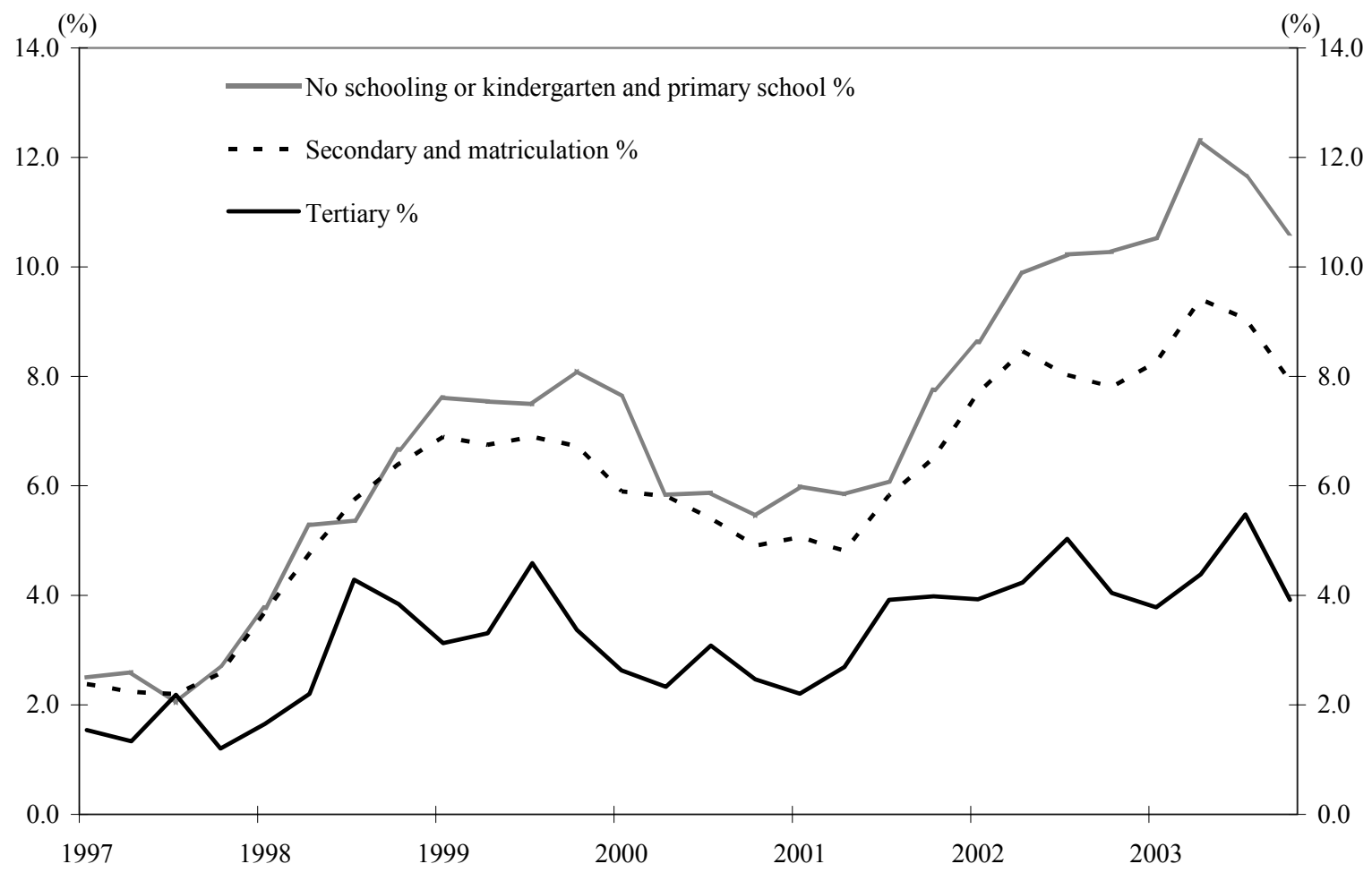

